\title{
Comprehensive Evaluation to a Prefabricated Building for Indoor Environment and Energy Consumption
}

\author{
Zhen Yang $\mathbb{D}^{1}{ }^{1}$ Xiang Li, ${ }^{1}$ Xuekai Zhang, ${ }^{2}$ and Qingwei Chen ${ }^{3}$ \\ ${ }^{1}$ China Electric Power Research Institute, Beijing 100192, China \\ ${ }^{2}$ State Grid Shandong Electric Power Company, Jinan, 250001 Shandong, China \\ ${ }^{3}$ Economic \& Technology Research Institute of State Grid Shandong Electric Power Company, Jinan, 250021 Shandong, China
}

Correspondence should be addressed to Zhen Yang; yangzhen1129@126.com

Received 15 September 2021; Revised 10 November 2021; Accepted 10 January 2022; Published 28 January 2022

Academic Editor: Chaofan Sun

Copyright (c) 2022 Zhen Yang et al. This is an open access article distributed under the Creative Commons Attribution License, which permits unrestricted use, distribution, and reproduction in any medium, provided the original work is properly cited.

Prefabricated building, as a convenient and burgeoning building form, is worth popularizing. The research is aimed at comprehensively evaluating and analyzing the indoor thermal environment, air quality, and energy consumption of prefabricated buildings. Therefore, indoor temperature distribution, airflow distribution, and energy system of prefabricated buildings are considered. Different building envelopes proposed accord with average temperature standard $\left(18^{\circ} \mathrm{C}\right)$ of indoor thermal environment in different climate regions based on simulation results of DeST software. Take the hot-summer and cold-winter region as an example, the distribution of the indoor temperature, air velocity, and the emission characteristics of indoor polluted particles are explored via ANSYS Fluent software. And the energy supply system for the prefabricated auxiliary building, as well as system operation performances and cost components, is studied. Results show the average indoor temperature on typical days in winter $\left(4.1^{\circ} \mathrm{C}\right)$ and summer $\left(31.1^{\circ} \mathrm{C}\right)$; air-source heat pump needs to activate for the needs of human thermal comfort. Moreover, the indoor air quality can meet the cleanliness standard after polluted particles release $40 \mathrm{~s}$. And the annual cost of system 1 (photovoltaic system, air-source heat pump, and the state grid) is $839.53 \$, 269.83 \$$ lower than system 2 (photovoltaic system, electrical storage, air-source heat pump, and the state grid), whereas the increase of electricity price can significantly reduce the payback period and thus improve the economy of system 2 . These findings provide suggestions in terms of indoor thermal environment, cleanliness, and suitable energy supply system to evaluate and facilitate the widespread application of buildings.

\section{Introduction}

Prefabricated buildings, as a major change in the way of construction and an important measure to rapidly promote the reform at the supply side and the development of new urbanization, has the characteristics of high efficiency, high quality, and high precision [1, 2]. However, with the continuous increase of the total number of buildings and the demand for indoor environment comfort, related problems that show how to improve the indoor thermal environment and reduce energy consumption of buildings have been severe challenges for relevant researchers. Operation personnel spends more than $70 \%$ of their time performing daily guard duty and having rest indoors, so improving the indoor environment of prefabricated buildings has attracted attention widely [3].
The prefabricated auxiliary building of substation is an important place for employees to work and live in the station. Therefore, indoor temperature of each room will affect the comfort of staff. As an important channel of heat exchange inside and outside of the building, the building envelope has an important influence on indoor temperature. The building envelope is also a critical factor in thermal comfort performance [4]. Yun et al. [5] carried out experimental studies and verified that adding phase change materials (PCM) into building envelopes can control heat load and adjust the room temperature to maintain acceptable thermal comfort. Van Helden et al. [6] noted that PCM played an important role in improving building efficiency and thermal comfort. And the usage of PCM in building products can provide appreciable temperature control in 
buildings, especially in those buildings that suffer from overheating in summer. Al-Yasiri and Szabo [7] mentioned that Trombe wall and thermally activated building technologies have improved the thermal performance of building envelope. In addition, Rabani et al. [8] considered the importance of building envelope and heating, ventilation, and air conditioning system parameters for indoor environment to meet the thermal comfort of occupants. Zhao et al. [9] presented the distribution of indoor-related parameters of the terminal and showed the wall and surface temperature at different locations by an infrared thermal imager. Kim et al. [10] used Computational Fluid Dynamics (CFD) software to simulate the thermal environment of the theatre and analyzed the simulation results of the airflow and temperature distribution in the space. Ali and Al-Hashlamun [11] compared the effect of building envelopes in old and new schools and evaluated the indoor thermal environment in classroom. Although earlier studies found in the literature have considered the effect of building envelopes on thermal comfort, inadequate efforts are found focusing on the investigation of building envelopes design under different climate zones for prefabricated building application. And the indoor temperature can be maintained within the appropriate range with the help of these schemes throughout the year.

In addition to the thermal comfort of personnel, indoor air quality or cleanliness is also closely related to employees' health. Especially in recent years, the occurrence of various public health problems makes indoor environmental safety more important. Previously, several researches have been carried out for the indoor air clean problem of the public buildings. Gabriel et al. [12] studied the new air volume influence on indoor pollutant control. The results showed that the increase in air volume improved air pollution in the rooms. He et al. [13] conducted field tests on 15 houses in Australia. Results show that indoor human activities on indoor particulate matter concentration mainly depend on the type of pollution sources and the layout characteristics of residential buildings. Yassin et al. [14] measured particulate matter with an aerodynamic diameter of less than $2.5 \mu \mathrm{m}\left(\mathrm{PM}_{2.5}\right)$ in different residential environments to assess indoor air quality. Agbo et al. [15] studied the methods of controlling indoor pollutant concentration and found that strengthening ventilation is the best and simplest way to improve the indoor air environment. Li et al. [16] studied the control strategy of indoor $\mathrm{PM}_{2.5}$ pollution in school classrooms. Zhang et al. [17] found that the new air control strategy with $\mathrm{PM}_{2.5}$ filters worked. In addition, introducing fresh air for air exchange can improve the indoor thermal environment and remove indoor pollutants without consuming mechanical energy. Hong et al. [18] found the removal efficiency of formaldehyde is the highest when the natural ventilation rate is $2 \mathrm{~m} / \mathrm{s}$ in decorated houses. Ncube and Riffat [19] proposed Indoor Environment Quality Assessment Tool to evaluate building thermal comfort, indoor air quality, acoustics, and lighting in an acceptable range. Madureira et al. [20] studied airborne bacterial and fungal concentrations in different indoor environments, i.e., homes, child day-care centers, primary schools, and elderly care centers to assess the risk of living environment.
Although the study considered various ways to improve indoor air quality, it was not investigated on indoor pollutant diffusion control on the basis of indoor ventilation conditions, especially in prefabricated auxiliary buildings.

A reasonable energy system can not only meet the users' loads but also reduce the external energy supply of buildings besides thermal comfort and air quantity of indoor environment. In recent years, many scholars have proposed different energy supply systems and applied them to a single building. Zabnienska-Gora et al. [21] proposed a photovoltaicthermal (PV/T) system that meets the annual thermal load requirements of two single-family buildings with low energy consumption. Isa et al. [22] demonstrated that a cogeneration system consisting of PV system, fuel cells, and batteries are an alternative to traditional power systems and achieves both thermal load and electrical load supply in hospital buildings. Marini et al. [23] proposed air source heat pump systems and thermal energy storage systems and dynamically simulated the space heating needs and hot water supply of residential buildings with 2 or 4 occupants. Zhang et al. [24] developed an alternative integrated electric energy system and considered different electrical-heating modes such as an electric boiler or electric heat pump. Liu et al. [25] proposed series connection between $\mathrm{PV} / \mathrm{T}$ and solar thermal collector, PV, and ground source hear pump to meet the needs of users' cold, heat, and electricity loads and apply it to nearly zero energy residential building, office building, and commercial building. Alayi et al. [26] investigated energy and economic performance of a solar cogeneration system in a building. The results showed that a solar collector with an area of about $7 \mathrm{~m}^{2}$ can provide all the heat load required for the building. And it saved natural gas consumption and reduced carbon dioxide emissions. Alessandro et al. [27] proposed an integrated "PV-thermal solar-assisted heat pump" system to meet all building heat load with a high proportion of renewable energy. Solar energy utilization and heat pump efficiency also increased in the system. Wang et al. [28] developed an integrated ground source heat pump-PVT to achieve the combined clean heating/cooling, reducing irreversible heat transfer losses and enhancing solar energy utilization efficiency. Although the previous studies considered indoor environment and pollutant control in buildings, the payback period and energy efficiency of the energy system varying with electricity price are rarely considered.

Based on the above considerations, research objects in current studies are not representative enough. Insufficient efforts are found, especially for the prefabricated auxiliary building with unique characteristics of small space residential function and of simple office function. Further, inadequate efforts are found focusing comprehensively from different perspectives to design and evaluate a prefabricated building, such as indoor thermal comfort, indoor cleanliness, energy supply system, and energy consumption.

The research is aimed at providing a comprehensive evaluation and analysis for a prefabricated auxiliary building, in terms of indoor environment and energy consumption. Therefore, the main contributions and innovation points of the study can be introduced as follows: (1) The indoor thermal comfort of prefabricated auxiliary buildings 
in different climate regions is investigated. And a variety of building envelope design under different climate zones is developed. (2) As a case study of the hot-summer and cold-winter region, the indoor temperature of prefabricated auxiliary building is studied from the spatial and temporal levels. (3) The airflow distribution in prefabricated auxiliary buildings is investigated. And the emission characteristics of indoor polluted particles from toilets are explored. (4) The energy supply system for the prefabricated auxiliary building, as well as system operation performances and cost components, is studied. And the impact of electricity price changes on the payback period is explored.

\section{System Model}

2.1. Mathematical Model. For the prefabricated auxiliary building, the photovoltaic system, air-source heat pump, and electrical storage are equipped to satisfy the electrical, heat, and cold loads for users. Related thermodynamic models are as follows.

2.1.1. Photovoltaic System (PV). The amount of electricity generated by $\mathrm{PV}$ system $\left(P_{\mathrm{pv}}, \mathrm{kW}\right)$ can be calculated by Equations (1)-(7) $[29,30]$.

$$
\begin{gathered}
P_{\mathrm{pv}}(t)=P_{0}(t) \times F_{\mathrm{t}}(t) \times F_{\mathrm{s}} \times F_{\mu} \times F_{\mathrm{o}}, \\
P_{0}(t)=I(t) \times V(t), \\
I(t)=I_{\mathrm{sc} 0}\left(\frac{\varphi_{\mathrm{rad}}(t)}{\varphi_{\mathrm{rad} 0}}-1\right)+I_{\mathrm{pm} 0}, \\
V(t)=V_{\mathrm{pm} 0} \times\left(1+0.0593 \times \lg \frac{\varphi_{\mathrm{rad}}(t)}{\varphi_{\mathrm{rad} 0}}\right), \\
F_{\mathrm{t}}(t)=1-\left(t_{\mathrm{pv}, \mathrm{real}}(t)-25\right) \times 0.5 \%, \\
t_{\mathrm{pv}, \text { real }}(t)=t_{\mathrm{amb}}(t)+30 \times \frac{\varphi_{\mathrm{rad}}(t)}{1000}, \\
f_{\mathrm{pv}}(t)=\frac{P_{\mathrm{pv}}(t)}{\varphi_{\mathrm{rad}}(t) \cdot S} .
\end{gathered}
$$

Herein, $P_{0}$ is the theoretical generating power of PV system, $\mathrm{kW} ; F_{\mathrm{s}}$ is the dust deposition factor, the ratio of the electric energy emitted by the photovoltaic panel during dust deposition to the initial electric energy emitted; $F_{\mu}$ is the performance mismatch factor of the system, which is caused by the failure of components to maintain the maximum power point output; $F_{0}$ is the influence of other factors, circuit aging, material aging caused by the reduction of power generation; $F_{\mathrm{t}}$ is the temperature correction factor; $I$ and $V$ are the working current and voltage of the photovoltaic panel, $\mathrm{A}, \mathrm{V} ; t_{\mathrm{pv}, \text { real }}$ is the operating temperature of the photovoltaic panel, ${ }^{\circ} \mathrm{C} ; \varphi_{\text {rad }}$ is the actual solar radiation received by the $\mathrm{PV}$ panel, $\mathrm{W} / \mathrm{m}^{2} ; \varphi_{\text {rado }}$ is the solar radiation received by the PV panel under standard conditions, $\mathrm{W} / \mathrm{m}^{2} ; t_{\mathrm{amb}}$ is the ambient temperature, ${ }^{\circ} \mathrm{C} ; I_{\mathrm{sc} 0}$ is the short-circuit current of PV system whose area is $S \mathrm{~m}^{2}, \mathrm{~A} ; I_{\mathrm{pm} 0}$ is the peak current of PV system whose area is $S \mathrm{~m}^{2}, \mathrm{~A} ; V_{\mathrm{pm} 0}$ is the peak voltage of PV system whose area is $S \mathrm{~m}^{2}, \mathrm{~V}$; and $f_{\mathrm{pv}}$ is power generation efficiency of the PV system.

2.1.2. Air-Source Heat Pump (AHP). The cold energy or heat energy generated by air-source heat pump can be calculated by Equations (8)-(11) [31].

$$
\begin{gathered}
\operatorname{PLR}_{\mathrm{AHP}}(t)=\frac{Q_{\mathrm{AHP}}(t)}{Q_{\mathrm{AHP}, \text { norm }}}, \\
\mathrm{COP}_{\mathrm{AHP}}=\mathrm{COP}_{\mathrm{AHP}, \text { norm }} \cdot \sum_{i=0}^{3}\left(a_{i} \cdot \mathrm{PLR}_{\mathrm{AHP}}^{i}\right), \\
Q_{\mathrm{AHP}}(t)=\mathrm{COP}_{\mathrm{AHP}} E_{\mathrm{AHP}}(t), \\
\left\{\begin{array}{l}
0 \leq Q_{\mathrm{AHP}}(t) \leq U_{0 / 1} \cdot Q_{\mathrm{AHP}, \max }, \\
Q_{\mathrm{AHP}}(t)=U_{0 / 1} \cdot Q_{\mathrm{AHP}, \max }\left(\text { if } Q_{\mathrm{AHP}}(t) \geq U_{0 / 1} \cdot Q_{\mathrm{AHP}, \max }\right) .
\end{array}\right.
\end{gathered}
$$

Herein, $Q_{\mathrm{AHP}}$ is the required cold energy or heating energy, $\mathrm{kW} ; Q_{\mathrm{AHP} \text {,norm }}$ is the rated cold energy or heating energy generated by $\mathrm{AHP}, \mathrm{kW} ; \mathrm{PLR}_{\mathrm{AHP}}$ is the load ratio; $\mathrm{COP}_{\mathrm{AHP}}$ is the coefficient of performance (COP) of AHP; $\mathrm{COP}_{\mathrm{AHP} \text {,norm }}$ is the rated coefficient of performance of AHP; $a_{i}$ is the polynomial fitting coefficient; $E_{\mathrm{AHP}}$ is power consumption, $\mathrm{kW} ; U_{0 / 1}$ is the on/off variable of AHP, which can only be 0 or 1 ; and $Q_{\mathrm{AHP} \text {, max }}$ is the maximum heat production or cold production of AHP, kW.

2.1.3. Electrical Storage (ES). The electricity stored in the battery at time $t\left(E_{\mathrm{ES}}(t), \mathrm{kWh}\right)$ is determined by Equation (12). The capacity constraint is determined by Equation (13), and the charge and discharge power are determined by Equations (14)- (17) [32].

$$
\begin{aligned}
& E_{\mathrm{ES}}(t)=E_{\mathrm{ES}}(t-1)+P_{\mathrm{ES}, \text { in }}(t) \cdot \Delta t \cdot \eta_{\mathrm{ES}, \text { in }}-P_{\mathrm{ES}, \text { out }}(t) \cdot \frac{\Delta t}{\eta_{\mathrm{ES}, \text { out }}}, \\
& E_{\mathrm{ES}, \min } \leq E_{\mathrm{ES}}(t) \leq E_{\mathrm{ES}, \text { max }}, \\
& \left\{\begin{array}{l}
P_{\mathrm{ES}, \text { in }}(t) \cdot P_{\mathrm{ES}, \text { out }}(t)=0, \\
P_{\mathrm{ES}, \text { in }}(t) \geq 0, \\
P_{\mathrm{ES}, \text { out }}(t) \geq 0,
\end{array}\right. \\
& \operatorname{SOC}_{\mathrm{ES}}(t)=\frac{E_{\mathrm{ES}}(t)}{E_{\mathrm{ES}, \max }}, \\
& P_{\mathrm{ES}, \text { in }}(t) \leq \min \left\{P_{\mathrm{ES}, \text { in, } \max }, \frac{\left[E_{\mathrm{ES}, \max }-E_{\mathrm{ES}}(t-1)\right]}{\Delta t \cdot \eta_{\mathrm{ES}, \text { in }}}\right\} \text {, } \\
& P_{\mathrm{ES}, \text { out }}(t) \leq \min \left\{P_{\mathrm{ES}, \text { out }, \mathrm{max}}, \frac{\left[E_{\mathrm{ES}}(t-1)-E_{\mathrm{ES}, \text { min }}\right]}{\Delta t} \cdot \eta_{\mathrm{ES}, \text { out }}\right\} .
\end{aligned}
$$

Herein, $E_{\mathrm{ES}}(t-1)$ is the stored electricity of the battery at time $t-1, \mathrm{kWh} ; P_{\mathrm{ES}, \text { in }}(t)$ and $P_{\mathrm{ES}, \text { out }}(t)$ are the charge and 


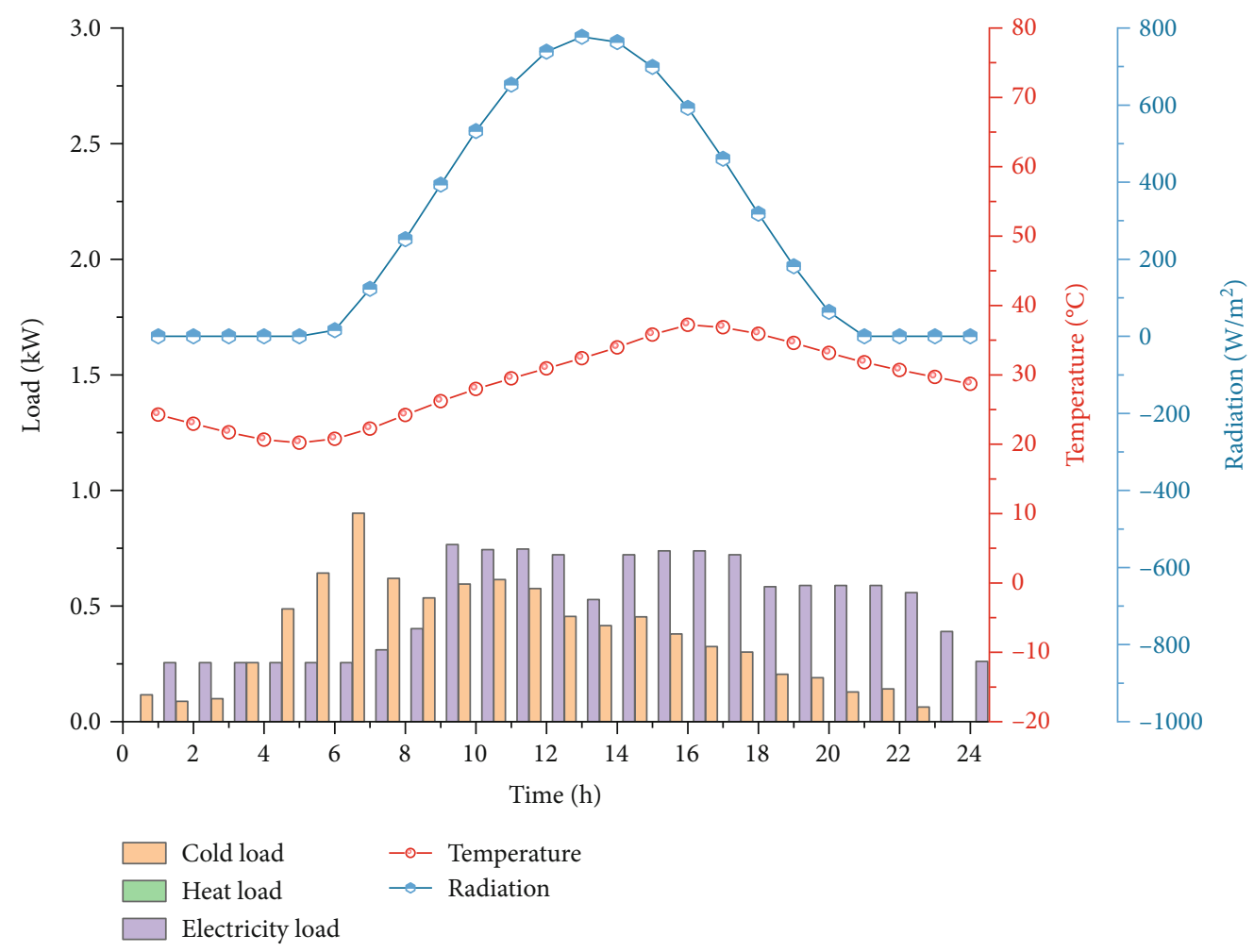

FIGURE 1: Meteorological parameters and users' loads on 15 Jul.

discharge powers of the battery at time $t, \mathrm{~kW} ; \eta_{\mathrm{ES} \text {,in }}$ and $\eta_{\mathrm{ES}, \text { out }}$ are the charge and discharge efficiency of the battery, respectively; $E_{\mathrm{ES} \text {,min }}$ and $E_{\mathrm{ES} \text {,max }}$ are the minimum and maximum storage capacity of the battery, $\mathrm{kWh} ; \mathrm{SOC}_{\mathrm{ES}}(t)$ is the state of charge of the battery at time $t ; P_{\mathrm{ES}, \text { in,max }}$ and $P_{\mathrm{ES}, \text { out,max }}$ are the maximum charge and discharge powers of the battery, $\mathrm{kW}$.

2.2. Payback Period (PBP). The payback period refers to the ratio of the difference between the total cost (except investment cost) of the reference system and that of the new system to the investment cost of the new system $\left(C_{1, \text { new }}, \$\right)$. A separated system is composed of the state grid and heat pump. The separated system is selected as a reference system. The PV system is considered in the new system, and more electricity can be sold to the state grid. The total cost of the reference system includes operation cost $\left(C_{2, \text { ref }}, \$\right)$, cost for purchase power $\left(C_{3 \text {,ref }}, \$\right)$, and investment cost $\left(C_{1, \text { ref }}, \$\right)$. And the total cost of the new system includes operation cost $\left(C_{2, \text { new }}, \$\right)$, cost for purchase power $\left(C_{3 \text {,new }}\right.$, $\$)$, benefit from grid $\left(C_{4, \text { new }}, \$\right)$, and investment cost $\left(C_{1, \text { new }}, \$\right)$.

$$
\begin{aligned}
\mathrm{PBP} & =\frac{\left(C_{\text {ref }}-C_{1, \text { ref }}\right)-\left(C_{\text {new }}-C_{1, \text { new }}\right)}{C_{1, \text { new }}} \\
& =\frac{\left(C_{2, \text { ref }}+C_{3, \text { ref }}\right)-\left(C_{2, \text { new }}+C_{3, \text { new }}+C_{4, \text { new }}\right)}{C_{1, \text { new }}},
\end{aligned}
$$

where $C_{1}$ is the investment cost, $\$ ; C_{2}$ is the operation cost,
$\$ ; C_{3}$ is the cost for purchase power, $\$$; and $C_{4}$ is the benefit from grid, $\$$. The added footnote 'ref' and 'new' indicate reference system and new system.

2.3. Operation Strategy of the System. In order to satisfy the user's loads of the prefabricated auxiliary building, two feasible energy supply systems are proposed. Herein, system 1 is composed of PV system and AHP. The electricity load of users is preferentially provided by PV system, and the deficiency is supplemented by grid. According to the solar radiation in Jinan and Equations (1)-(7), power generation of PV system is calculated. If PV system meets the electricity load and there is a surplus, this part will give priority to driving the AHP for refrigeration in summer and heating in winter. According to Equations (8)-(11), the electricity required by AHP for heating and cooling can be calculated. The surplus electricity is sold to the grid, and the insufficient load is supplemented by power purchase. In order to reduce the impact to power grid and improve the comprehensive performance indexes of the system, the battery is added in system 2 based on system 1 . In system 2 , the excess electricity generated by PV system is stored in the battery and discharged to supplement when the load is insufficient. The AHP can be driven by the electricity from the PV system, battery, and grid to supply heat energy and cold energy to users.

\section{Case Study}

3.1. Meteorological Parameter Information. Jinan is classified as the hot-summer and cold-winter regions. The optimal 


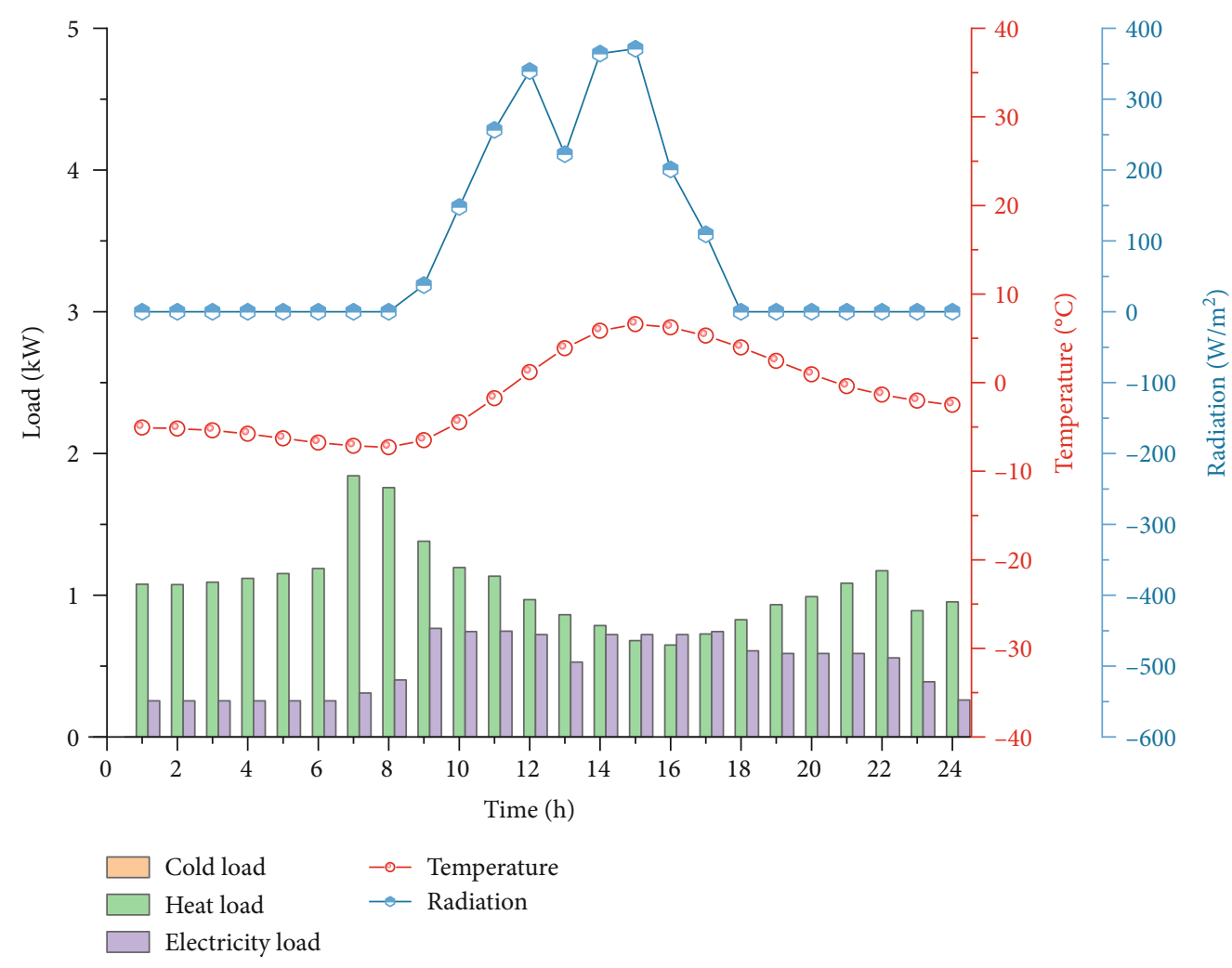

Figure 2: Meteorological parameters and users' loads on 15 Jan.

inclined angle of PV panels is $32^{\circ}$, according to the geographical location of Jinan city, Shandong province. Outdoor meteorological parameters and users' loads of typical day in summer and winter in Jinan are shown in Figure 1 and 2. The typical day in summer (15 Jul) represents relatively ample cold load in summer, and electricity load exists meanwhile. And the typical day (15 Jan) is the representative in winter that there is electricity load and considerable heat load [33]. As seen in Figure 1, the average temperature on July $15^{\text {th }}$ is nearly $30^{\circ} \mathrm{C}$. Also, the maximum solar radiation in the day is approximately $800 \mathrm{kWh} / \mathrm{m}^{2}$. There are massive cold load and electricity load in summer. Electricity load covers the whole day. In addition to users' rest time at night, electricity load remains at a relatively high level, about $0.86 \mathrm{~kW}$. Throughout the day, the electricity load of users is larger than the heat load. As seen in Figure 2, the minimum temperature on typical day in winter is $-8^{\circ} \mathrm{C}$ and the maximum temperature is $9^{\circ} \mathrm{C}$. The average temperature on January $15^{\text {th }}$ is around $0^{\circ} \mathrm{C}$. Also, the available solar irradiance ranges from 9:00 to 18:00, and the solar irradiance reaches the maximum of $391 \mathrm{~W} / \mathrm{m}^{2}$ at $14: 00$. There is only electricity load and heat load on January 15th, and it is covered all day. Obviously, the heat load is in higher demand.

3.2. Building Information. Jian et al. [34] studied prefabricated buildings with PCM in different climates. The results show that only the building envelopes of prefabricated buildings are distinct in different climatic zones, but all of them can meet the indoor environmental temperature requirements of different climate zones. Therefore, based on that,

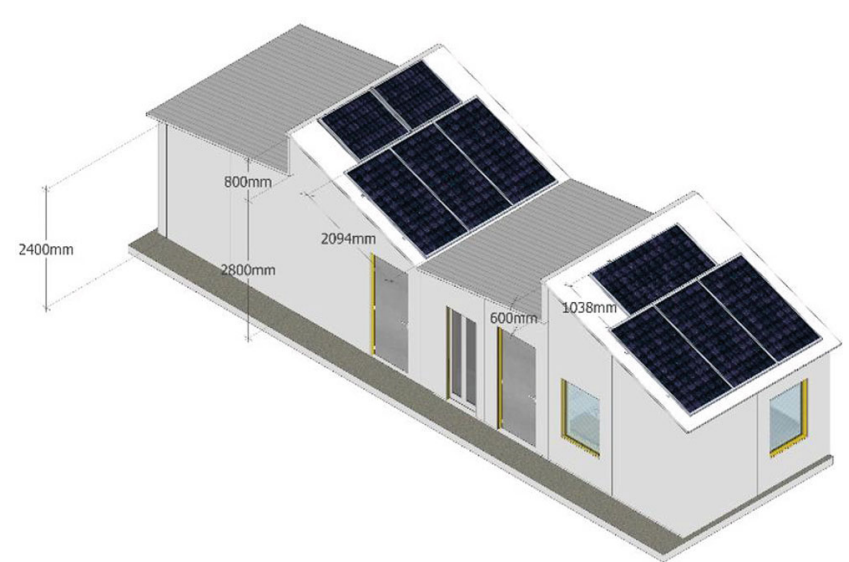

FIgURE 3: Outside view of the prefabricated auxiliary building.

a hot-summer and cold-winter region, Jinan, is selected as a representative case study to carry out the case study. It can reflect the situation of other climate regions. As shown in Figure 3, the studied object, a prefabricated auxiliary building of the substation located in Jinan city, Shandong province, is used to provide a place for substation staff to rest and be on guard. The prefabricated building has a minimum height of $2.4 \mathrm{~m}$ and a maximum height of $3.6 \mathrm{~m}$. The roof is inclined to facilitate the placement of photovoltaic panels and improve the photoelectric conversion efficiency. The inclined angle is determined according to the local solar irradiation angle. For different climate regions, the enclosure 


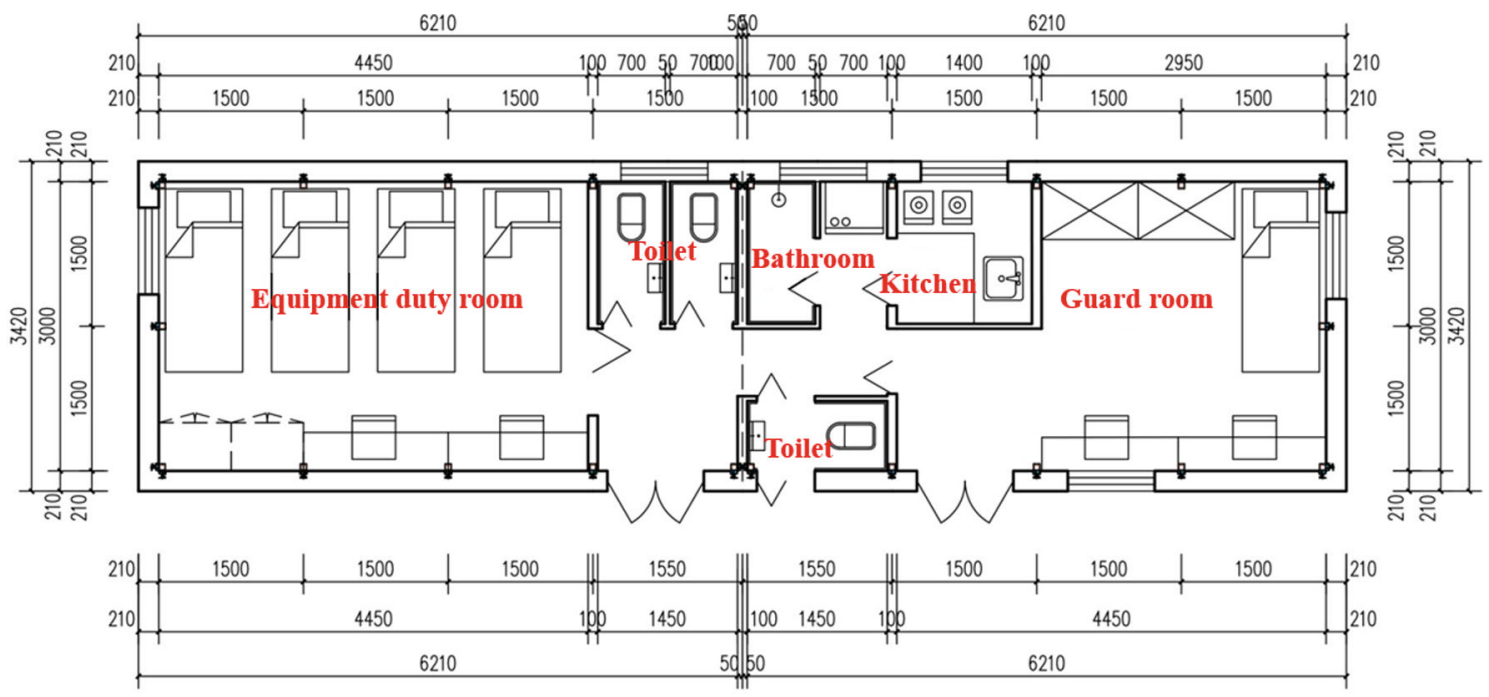

FIGURE 4: Interior plan of the prefabricated auxiliary building.

TABLE 1: The main building envelope information for different climatic regions.

\begin{tabular}{|c|c|c|c|c|c|c|}
\hline \multirow{2}{*}{ Climatic regions } & \multicolumn{2}{|l|}{ Roof } & \multicolumn{2}{|c|}{ Exterior wall } & \multicolumn{2}{|l|}{ Ground } \\
\hline & Materials & $k\left(\mathrm{~W} / \mathrm{m}^{2} \cdot \mathrm{K}\right)$ & Materials & $k\left(\mathrm{~W} / \mathrm{m}^{2} \cdot \mathrm{K}\right)$ & Materials & $k\left(\mathrm{~W} / \mathrm{m}^{2} \cdot \mathrm{K}\right)$ \\
\hline Severe cold region & $\begin{array}{c}\text { Cement mortar } \\
20 \mathrm{~mm} \\
\text { Asphalt concrete } \\
80 \mathrm{~mm} \\
\text { Polystyrene foamed } \\
\text { plastics } 200 \mathrm{~mm} \\
\text { Lime mortar } 15 \mathrm{~mm} \\
\text { Polyurethane foam } \\
100 \mathrm{~mm}\end{array}$ & 0.10 & $\begin{array}{c}\text { Cement mortar } 30 \mathrm{~mm} \\
\text { Guangdong ceramsite } \\
\text { concrete } 100 \mathrm{~mm} \\
\text { Polyurethane foam } \\
285 \mathrm{~mm} \\
\text { Guangdong ceramsite } \\
\text { concrete } 200 \mathrm{~mm} \\
\text { Lime mortar } 30 \mathrm{~mm}\end{array}$ & 0.10 & $\begin{array}{l}\text { Polyurethane foam } \\
\qquad 100 \mathrm{~mm} \\
\text { Stone masonry } 200 \mathrm{~mm} \\
\text { Perlite } 180 \mathrm{~mm} \\
\text { Polyvinyl chloride } \\
\text { foamed plastics } 180 \mathrm{~mm}\end{array}$ & 0.10 \\
\hline Cold region & $\begin{array}{c}\text { Cement mortar } \\
15 \mathrm{~mm} \\
\text { Polyurethane foamed } \\
\text { plastics } 173 \mathrm{~mm} \\
\text { Expanded perlite } \\
160 \mathrm{~mm} \\
\text { Cement mortar } \\
15 \mathrm{~mm}\end{array}$ & 0.15 & $\begin{array}{l}\text { Cement mortar } 30 \mathrm{~mm} \\
\text { Guangdong ceramsite } \\
\text { concrete } 100 \mathrm{~mm} \\
\text { Polystyrene foamed } \\
\text { plastics } 280 \mathrm{~mm} \\
\text { Guangdong ceramsite } \\
\text { concrete } 20 \mathrm{~mm} \\
\text { Lime mortar } 30 \mathrm{~mm}\end{array}$ & 0.15 & $\begin{array}{l}\text { Polyurethane foamed } \\
\text { plastics } 90 \mathrm{~mm} \\
\text { Ceramsite concrete } \\
210 \mathrm{~mm} \\
\text { Expanded perlite } \\
100 \mathrm{~mm}\end{array}$ & 0.15 \\
\hline $\begin{array}{l}\text { Hot-summer and } \\
\text { cold-winter region }\end{array}$ & $\begin{array}{l}\text { Cement mortar } \\
20 \mathrm{~mm} \\
\text { Urea moulding } \\
\text { material } 160 \mathrm{~mm} \\
\text { Expanded perlite } \\
250 \mathrm{~mm} \\
\text { Cement mortar } \\
20 \mathrm{~mm}\end{array}$ & 0.20 & $\begin{array}{c}\text { Cement mortar } 15 \mathrm{~mm} \\
\text { Guangdong ceramsite } \\
\text { concrete } 180 \mathrm{~mm} \\
\text { Polystyrene foamed } \\
\text { plastics } 200 \mathrm{~mm} \\
\text { Guang dong mortar } \\
\text { malm brick } 180 \mathrm{~mm} \\
\text { Lime mortar } 15 \mathrm{~mm}\end{array}$ & 0.20 & $\begin{array}{l}\text { Polyurethane foam } \\
53 \mathrm{~mm} \\
\text { Ceramsite concrete } \\
200 \mathrm{~mm} \\
\text { Expanded perlite } \\
100 \mathrm{~mm}\end{array}$ & 0.20 \\
\hline $\begin{array}{l}\text { Hot-summer and } \\
\text { warm-winter region }\end{array}$ & $\begin{array}{l}\text { Polyurethane } 2 \mathrm{~mm} \\
\text { Polystyrene foamed } \\
\text { plastics } 110 \mathrm{~mm} \\
\text { Polyurethane } 2 \mathrm{~mm}\end{array}$ & 0.40 & $\begin{array}{c}\text { Cement mortar } 35 \mathrm{~mm} \\
\text { Expanded perlite } \\
83 \mathrm{~mm} \\
\text { Cement mortar } 35 \mathrm{~mm}\end{array}$ & 0.50 & $\begin{array}{l}\text { Cement mortar } 20 \mathrm{~mm} \\
\text { Calcium plastic } 60 \mathrm{~mm} \\
\text { Sandstone and quartzite } \\
20 \mathrm{~mm}\end{array}$ & 0.80 \\
\hline Warm region & $\begin{array}{l}\text { Cement mortar } \\
20 \mathrm{~mm} \\
\text { Urea moulding } \\
\text { material } 160 \mathrm{~mm} \\
\text { Expanded perlite } \\
250 \mathrm{~mm} \\
\text { Cement mortar } \\
20 \mathrm{~mm}\end{array}$ & 0.20 & $\begin{array}{c}\text { Cement mortar } 35 \mathrm{~mm} \\
\text { Expanded perlite } \\
83 \mathrm{~mm} \\
\text { Cement mortar } 35 \mathrm{~mm}\end{array}$ & 0.50 & $\begin{array}{c}\text { Cement mortar } 20 \mathrm{~mm} \\
\text { Calcium plastic } 97 \mathrm{~mm} \\
\text { Sandstone and quartzite } \\
20 \mathrm{~mm}\end{array}$ & 0.50 \\
\hline
\end{tabular}


TAble 2: Parameter settings in DeST simulation [41].

\begin{tabular}{|c|c|c|c|c|c|}
\hline Rooms & $\begin{array}{l}\text { Number of } \\
\text { personnel }\end{array}$ & $\begin{array}{l}\text { Average calorific value of } \\
\text { indoor persons (W) }\end{array}$ & $\begin{array}{c}\text { Light thermal } \\
\text { disturbance }\left(\mathrm{W} / \mathrm{m}^{2}\right)\end{array}$ & $\begin{array}{c}\text { Thermal disturbance of } \\
\text { equipment }\left(\mathrm{W} / \mathrm{m}^{2}\right)\end{array}$ & $\begin{array}{c}\text { Air } \\
\text { conditioning } \\
\text { system }\end{array}$ \\
\hline Bathroom & 1 & 66 & 18 & 13 & $6: 00-21: 00$ On \\
\hline Kitchen & 4 & 66 & 13 & 20 & Fully closed \\
\hline $\begin{array}{l}\text { Equipment } \\
\text { duty room }\end{array}$ & 2 & 62 & 18 & 11 & Fully opened \\
\hline Lounge & 4 & 61 & 11 & 11 & Fully opened \\
\hline
\end{tabular}

structure is different. Figure 4 shows the interior plan of the prefabricated auxiliary building. It has a total length of about $12.5 \mathrm{~m}$ and a total width of about $3.4 \mathrm{~m}$, which covers an area of about $42.8 \mathrm{~m}^{2}$. The prefabricated building mainly includes the equipment duty room, the guard room, the bathroom, the kitchen, and three toilets.

3.3. Parameter Settings. There are five climate regions in China, which include severe cold region, cold region, hotsummer and cold-winter region, hot-summer and warmwinter region, and warm region, respectively. Correspondingly, the prefabricated auxiliary buildings have different materials and sizes of the building envelope, and the roof inclination angles are changed accordingly. In the severe cold region and cold region, insulation is a main factor of the building envelope. Materials with small thermal conductivity are selected, and the thickness of materials is relatively thick, which leads to a smaller overall heat transfer coefficient. In hot-summer and cold-winter region, the massive energy consumption of heating in winter and cooling in summer induces the selection of suitable insulation and thermal insulation performance. The heat transfer coefficient of building envelope is small, and the material thickness is relatively thin. In hot-summer and warm-winter region and warm region, materials with smaller thermal conductivity are selected, so that heat transfer coefficients of the roof and floor are relatively small. The indoor ambient temperatures building loads of the above conditions are simulated in DeST software. The indoor temperature in different climate zones follows industry standards [35]. So far, a large number of case studies and theoretical verifications have been carried out on DeST [36-38]. And DeST software with accurate and reliable performance has been widely used to develop building models and simulate cold, heat, and electricity loads. Shi et al. [39] calculated the coefficient of variation of the root-mean square error (RMSE) to compare the error between simulated and measured values. The results show that the value of RMSE is 0.63 , indicating that the simulation data using DeST is consistent with the measured data, and the error is acceptable in the field of building simulation. The accuracy of DeST simulation method is further verified. Therefore, only simulation experiments are carried out; it can also accurately reflect the real situation. Among them, the relevant parameter settings in the simulation process are shown in Tables 1 and 2. Building envelops are suitable for five different climate regions. The thermal conduction coefficients of building envelop (i.e., roof, exterior
TABle 3: Technical parameters of energy supply system [47-49].

\begin{tabular}{|c|c|c|}
\hline Items & & Values \\
\hline \multirow{8}{*}{ PV } & $S\left(\mathrm{~m}^{2}\right)$ & $8 \times 2.17$ \\
\hline & $I_{\mathrm{sc} 0}(\mathrm{~A})$ & 7.91 \\
\hline & $I_{\mathrm{pm} 0}(\mathrm{~A})$ & 7.45 \\
\hline & $V_{\mathrm{pm} 0}(\mathrm{~V})$ & 36.1 \\
\hline & $\varphi_{\mathrm{rad} 0}\left(\mathrm{~W} / \mathrm{m}^{2}\right)$ & 1000 \\
\hline & $F_{\mathrm{s}}$ & 0.98 \\
\hline & $F_{\mu}$ & 0.95 \\
\hline & $F_{\mathrm{o}}$ & 0.98 \\
\hline \multirow{6}{*}{ AHP (refrigeration/heating) } & $Q_{\mathrm{AHP}, \text { norm }}(\mathrm{kW})$ & $4 / 2$ \\
\hline & $\mathrm{COP}_{\mathrm{AHP}, \text { norm }}$ & $3.30 / 2.80$ \\
\hline & $a_{0}$ & 1.65 \\
\hline & $a_{1}$ & 1.30 \\
\hline & $a_{2}$ & 1.14 \\
\hline & $Q_{\mathrm{AHP}, \max }(\mathrm{kW})$ & $4 / 2$ \\
\hline \multirow{6}{*}{ ES } & $\eta_{\mathrm{ES}, \text { in }}$ & 0.945 \\
\hline & $\eta_{\mathrm{ES}, \text { out }}$ & 0.945 \\
\hline & $E_{\mathrm{ES}, \min }(\mathrm{kWh})$ & 2 \\
\hline & $E_{\mathrm{ES}, \max }(\mathrm{kWh})$ & 8 \\
\hline & $P_{\mathrm{ES}, \mathrm{in}, \max }(\mathrm{kW})$ & 2 \\
\hline & $P_{\mathrm{ES}, \text { out }, \text { max }}(\mathrm{kW})$ & 2 \\
\hline
\end{tabular}

TABLE 4: Economic parameters and capacity of equipment in energy supply system [50].

\begin{tabular}{lcccccc}
\hline \multirow{2}{*}{ Equipment } & \multicolumn{2}{c}{ Investment } & \multicolumn{2}{c}{ Operation cost } & \multicolumn{2}{c}{ Capacity } \\
& Value & Unit & Value & Unit & Value & Unit \\
\hline PV & 315 & $\$ / \mathrm{m}^{2}$ & 25.26 & $\$ / \mathrm{m}^{2}$ & $8^{*} 2.17$ & $\mathrm{~m}^{2}$ \\
ES & 345 & $\$ / \mathrm{kWh}$ & 27.67 & $\$ / \mathrm{kWh}$ & 8 & $\mathrm{kWh}$ \\
AHP & 240 & $\$ / \mathrm{kW}$ & 19.25 & $\$ / \mathrm{kW}$ & 3.96 & $\mathrm{kWh}$ \\
\hline
\end{tabular}

wall, and ground) listed in Table 1 are referenced to Chinese criterion of "Design Standard for Energy Efficiency of Public Buildings (GB 50189-2005)" [40]. The heat transfer coefficient standard of the roof, exterior wall, and the ground of the passive building is within a range in different climate 


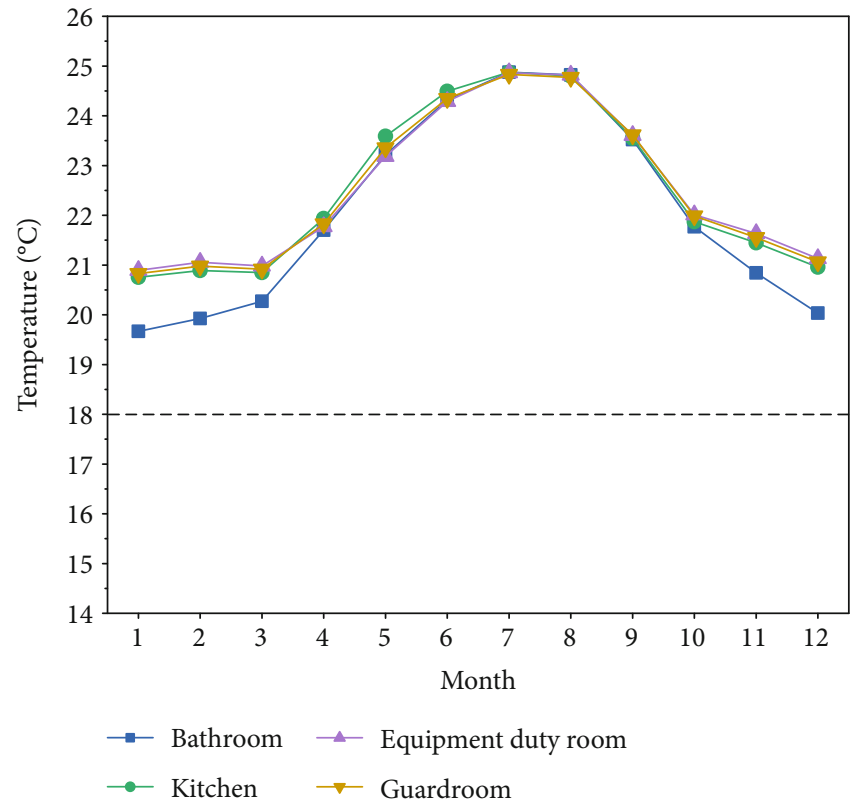

(a) Severe cold region

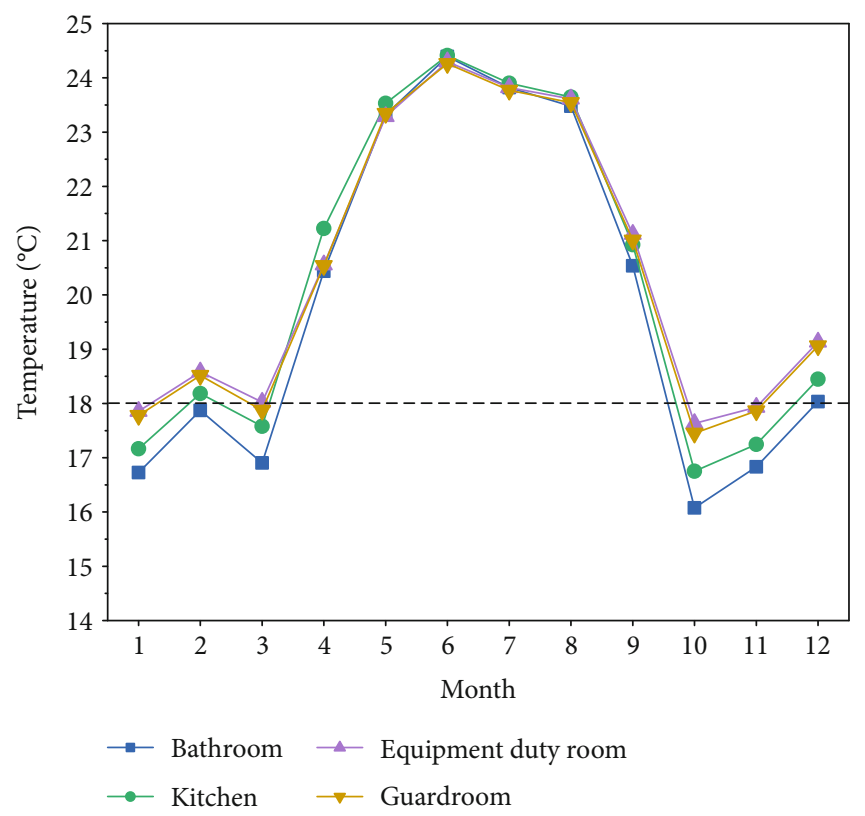

(c) Hot-summer and cold-winter region

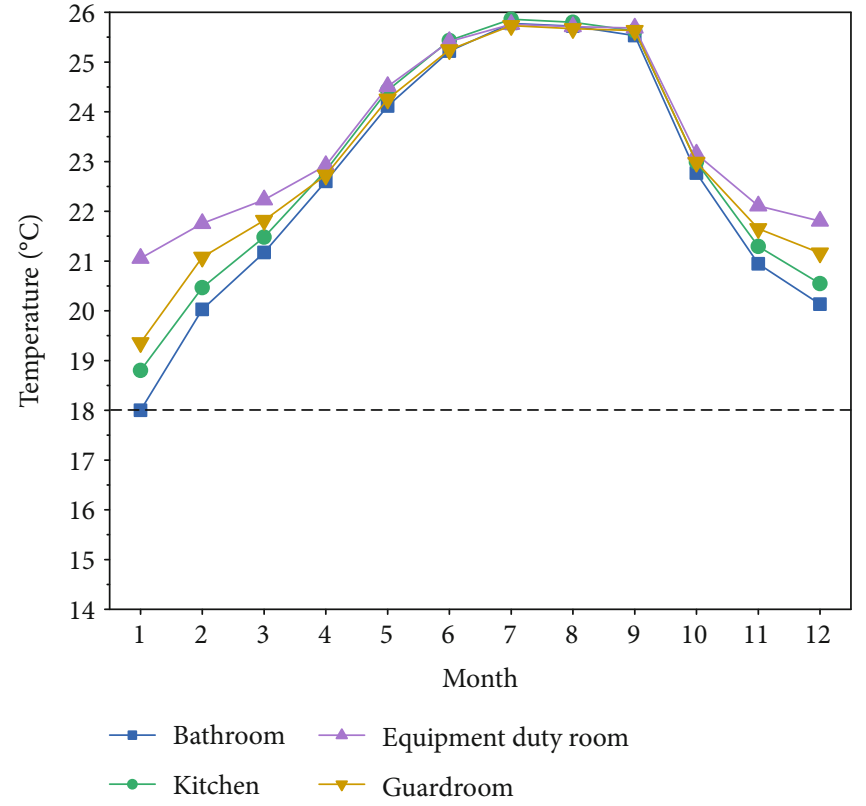

(b) Cold region

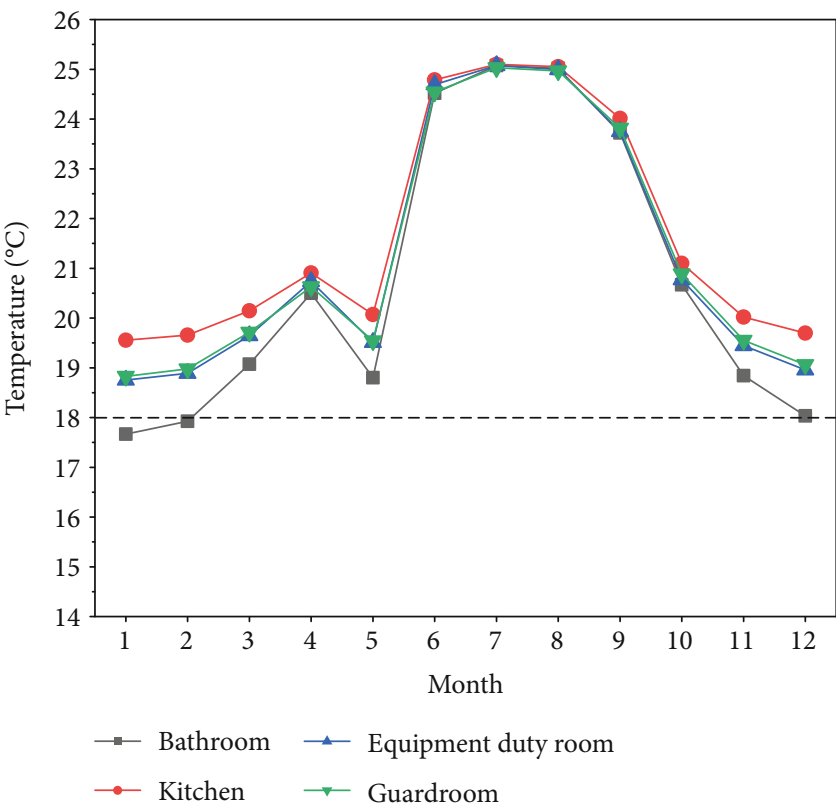

(d) Hot-summer and warm-winter region

Figure 5: Continued. 


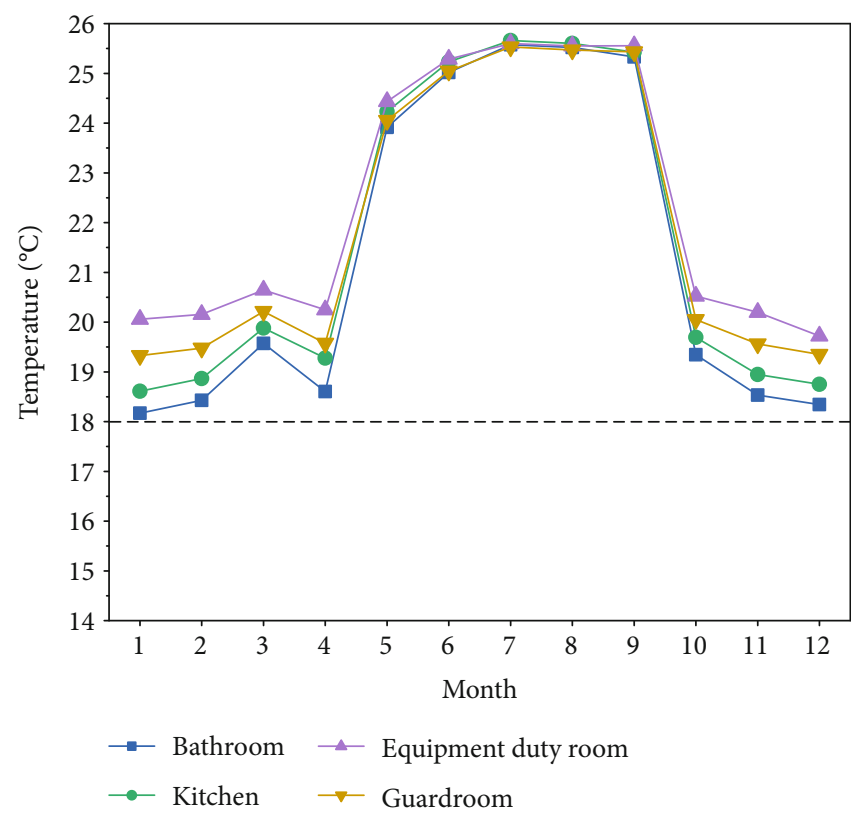

(e) Warm region

FIgURE 5: Monthly indoor average temperature of rooms in different climate regions.

zones and is not a definite value. For example, in a severe cold region, the heat transfer coefficient of exterior wall and roof is in the range from 0.10 to 0.20 . And the heat transfer coefficient of the ground is in the range of 0.10-0.25. In our study, the heat transfer coefficients of the roof, exterior wall, and floor in severe cold regions are $0.10 \mathrm{~W} / \mathrm{m}^{2} \mathrm{~K}$. These values are selected based on "Design Standard for Energy Efficiency of Public Buildings (GB 50189-2005)" [40]. And on the basis of reasonable indoor thermal comfort and relatively low energy consumption of the prefabricated building, these heat transfer coefficients are obtained.

For the energy supply system of the prefabricated auxiliary building, related technical parameters, economic parameters, and equipment capacity of the system are set as Tables 3 and 4, according to the local indexes in Jinan city, Shandong province.

The area of PV system, the capacity of AHP, and ES are not optimized in detail. However, the area of PV system is designed on the basis of the orientation of the building and the structure of the roof. PV panels are all at optimal angle and arranged in the southern orientation. The capacity of AHP is set according to the electricity generated by PV system and users' heat load and cold load. ES is introduced into the energy system to investigate the effect on the overall economy and energy consumption of the system via the comparison between system 1 and system 2 . And the capacity of ES is designed on the basis of consideration of users' loads. Especially, models with constant COP were used in Ref. [42-45] and achieved good results; it was proved that this model can be studied and the accuracy meets the engineering requirements. And COP is a model that changed with partial load rate (according to Ref. [46]). But when the load level exceeds 0.4, COP is close to the constant, so the constant model adopted in this paper is also acceptable.

\section{Results and Discussion}

4.1. Monthly Average Indoor Temperatures of Different Climate Regions. For five climate regions, the monthly average indoor ambient temperatures of each room are presented in Figure 5. As seen in Figures 5(a) and 5(b), the average indoor temperatures are in the range of $19^{\circ} \mathrm{C}-25^{\circ} \mathrm{C}$ for the severe cold region and $18^{\circ} \mathrm{C}-26^{\circ} \mathrm{C}$ for the cold region. Especially in winter, the overall temperature level in the severe cold region is higher than that in the cold region, which is due to the better performance of the envelope of the severe cold region. Also in winter, there is a great temperature difference among different rooms. The lowest temperature occurs in the bathroom, which is $19.5^{\circ} \mathrm{C}$ in the severe cold region and $18^{\circ} \mathrm{C}$ in the cold region. Therefore, the monthly average indoor ambient temperatures meet the Code for Design of Heating Ventilation and Air Conditioning (reach to $18^{\circ} \mathrm{C}$ ) [52]. Figures 5(c) and 5(d) show the monthly average indoor ambient temperatures of the rooms in the hot-summer and cold-winter region and the hot-summer and warm-winter region. For different rooms, the temperature difference is very significant in winter but not in summer. Because of the existed the air conditioners, the ambient temperature is not particularly low in the hotsummer and warm-winter region and even the indoor temperature raised in November and December in the hotsummer and cold-winter region. The lowest indoor temperature occurs in bathroom, which is about $16^{\circ} \mathrm{C}$ in the hot-summer and cold-winter region, and about $17.5^{\circ} \mathrm{C}$ in the hot-summer and warm-winter region. Especially, the average indoor temperature in all rooms except the bathroom was up to the heating standard in the hot-summer and warm-winter region. For the hot-summer and coldwinter region, the average indoor temperature in all rooms 


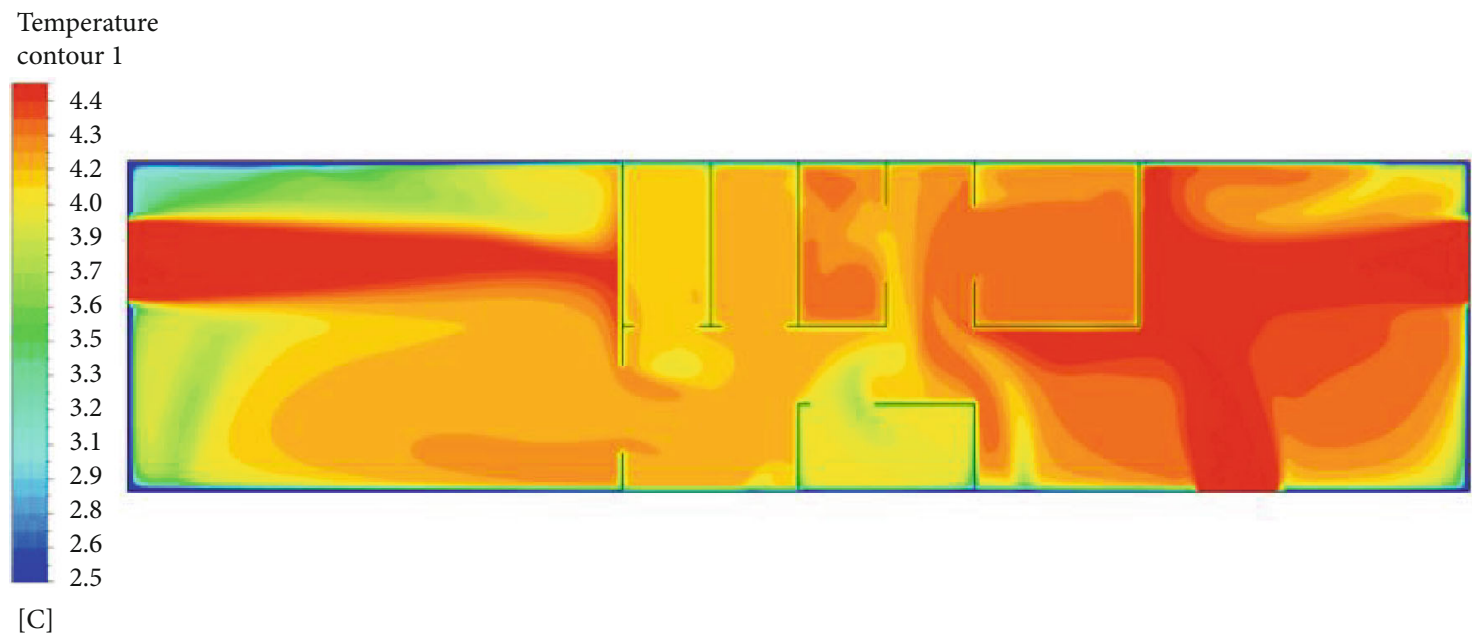

(a) Indoor temperature distribution

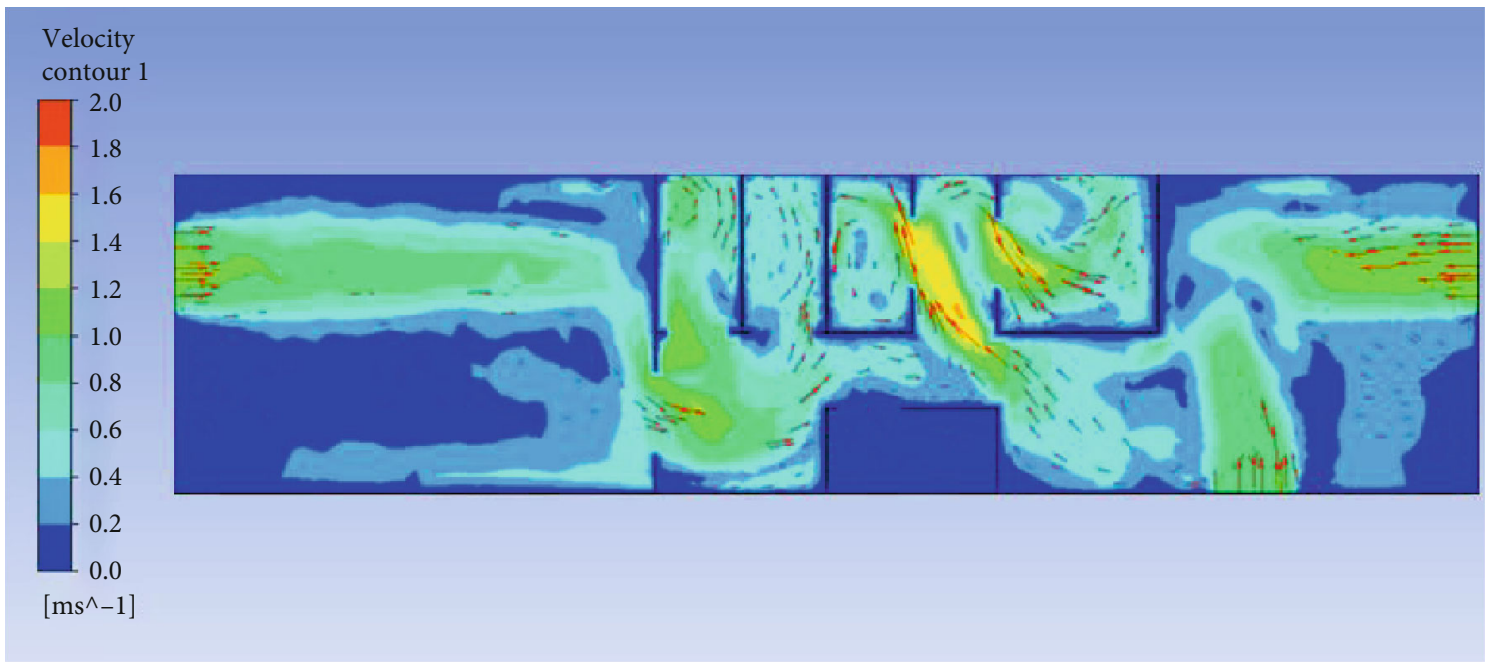

(b) Indoor air velocity distribution

Figure 6: Distribution of indoor temperature and air velocity on 15 Jan.

except the bathroom and kitchen was basically meet the heating standard. The average indoor temperatures of the rooms in the warm region are shown in Figure 5(e). The temperature difference of different rooms mainly occurs in winter. There is the lowest temperature of $18^{\circ} \mathrm{C}$ in the bathroom. The temperature level of each room can meet the relevant temperature requirements of the heating standard. Therefore, the average indoor temperatures of the prefabricated building can basically reach the heating standard of each climate region with building envelopes with different performance.

4.2. Indoor Thermal Environment and Airflow Distribution of Typical Days. The indoor temperature and air velocity distribution in the prefabricated building are simulated through ANSYS Fluent software. It is assumed that the building's indoor air is incompressible and conforms to the Boussinesq hypothesis; the thermal radiation between walls is ignored to facilitate the calculation. It is believed that indoor air tightness is good without the influence of air leakage. On the background of meteorological conditions in Jinan City, Shandong Province (the hot-summer and cold-winter region), $15 \mathrm{Jan}$ and $15 \mathrm{Jul}$ are selected as typical days in winter and summer. The corresponding outdoor average temperature is $4.5^{\circ} \mathrm{C}$ and $32^{\circ} \mathrm{C}$, respectively. The average air velocity is $1 \mathrm{~m} / \mathrm{s}$ and $1.5 \mathrm{~m} / \mathrm{s}$, respectively. The air velocity and temperature distribution at the height of human activity ( $1.5 \mathrm{~m}$ from the ground) are selected for analysis.

Figure 6(a) shows the daily average indoor temperature distribution on 15 Jan. The average indoor temperature is $4.1^{\circ} \mathrm{C}$ of the prefabricated auxiliary building, and the overall temperature level of the equipment duty room is the highest. The highest average temperature is $4.4^{\circ} \mathrm{C}$ occurred in the guard room. Due to the temperature attenuation characteristics in the process of gas flow, the average temperature in the bathroom and kitchen is about $4.2^{\circ} \mathrm{C}$, slightly lower than that of equipment duty room. Figure 6(b) shows the daily average indoor airflow distribution on 15 Jan. It can be seen that the maximum indoor air velocity is $1.8 \mathrm{~m} / \mathrm{s}$, which occurs in the corridor of the toilets and kitchen. The reason is that the 


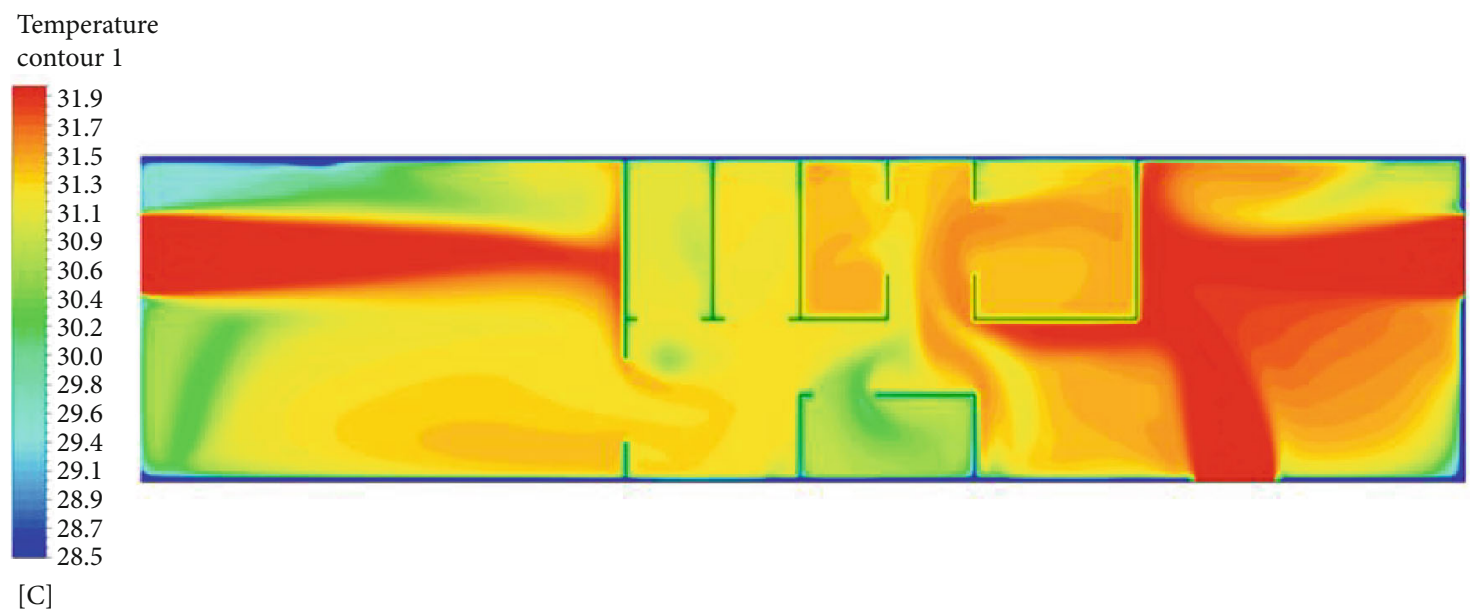

(a) Indoor temperature distribution

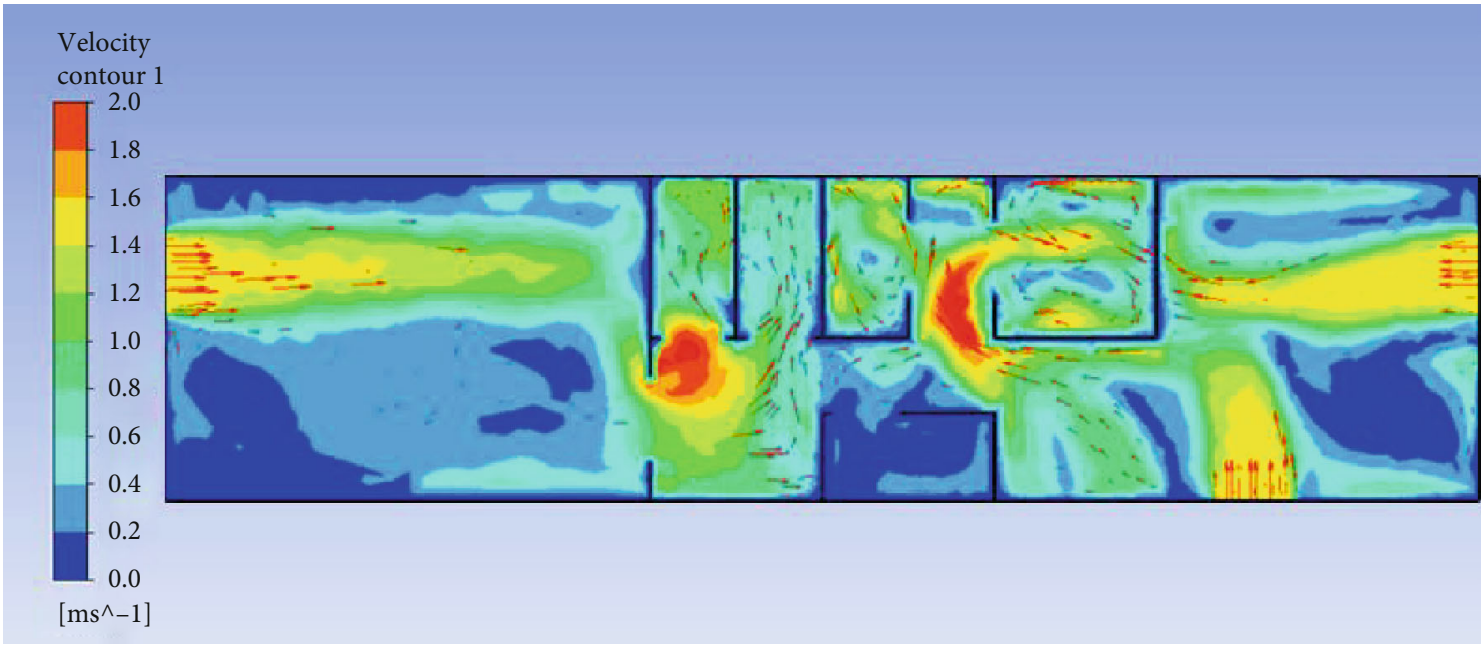

(b) Indoor air velocity distribution

FIGURE 7: Distribution of indoor temperature and air velocity on $15 \mathrm{Jul}$.

multiple air flows converge here driven by exhaust fan in toilets, resulting in the maximum air velocity. The overall average indoor air velocity is $0.5 \mathrm{~m} / \mathrm{s}$, and there is no obvious airflow dead corner in the rooms. Moreover, the standard of air velocity in the area where people stay for a long time is $0.8 \mathrm{~m} / \mathrm{s}$ [53]. Therefore, people have no apparent draught sensation in the prefabricated auxiliary room in winter.

Figure 7 (a) shows the daily average indoor temperature distribution on 15 Jul. The overall average indoor temperature is $31.1^{\circ} \mathrm{C}$. The highest indoor temperature is $31.9^{\circ} \mathrm{C}$, which also occurs in the guard room. On the whole, the building meets the thermal comfort requirements. However, natural ventilation alone at midday is not enough, and it is necessary to turn on air conditioners in the guard room and duty room for cooling. Figure 7 (b) shows the daily average indoor airflow distribution on 15 Jan. It can be seen that indoor air velocity is basically uniform, with an average air velocity of $0.7 \mathrm{~m} / \mathrm{s}$. The maximum air velocity also occurs in the corridor of the bathroom and kitchen $(2 \mathrm{~m} / \mathrm{s})$. On the whole, the air velocity in the room is suitable, and there is no apparent airflow dead corner in the working area. Also, people have no apparent draught sensation in the prefabricated auxiliary room in summer.

On 15 Jan. and 15 Jul., the average indoor temperature of each functional room is shown in Figure 8. It can be seen that the overall average indoor temperature of guard room is the highest among the rooms, whether in summer or winter, while the equipment duty room has the lowest temperature level in winter and the moderate temperature level in summer among the rooms. Therefore, AHP needs to be turned on to provide cold energy in summer and heat energy in winter for the rooms to maintain indoor thermal comfort.

4.3. Emission Characteristics of Indoor Polluted Particles. In the prefabricated auxiliary building, three toilets are the site of produced polluted particles. To study whether the particles emitted from three toilets can be discharged by the ventilation system in time, ANSYS Fluent software is adopted to simulate the emission characteristics of particles from toilets. There is an exhaust fan on the wall of each toilet to remove polluted particles. In the simulation, the RNG K-epsilon model is adopted to simulate the indoor airflow field. In 


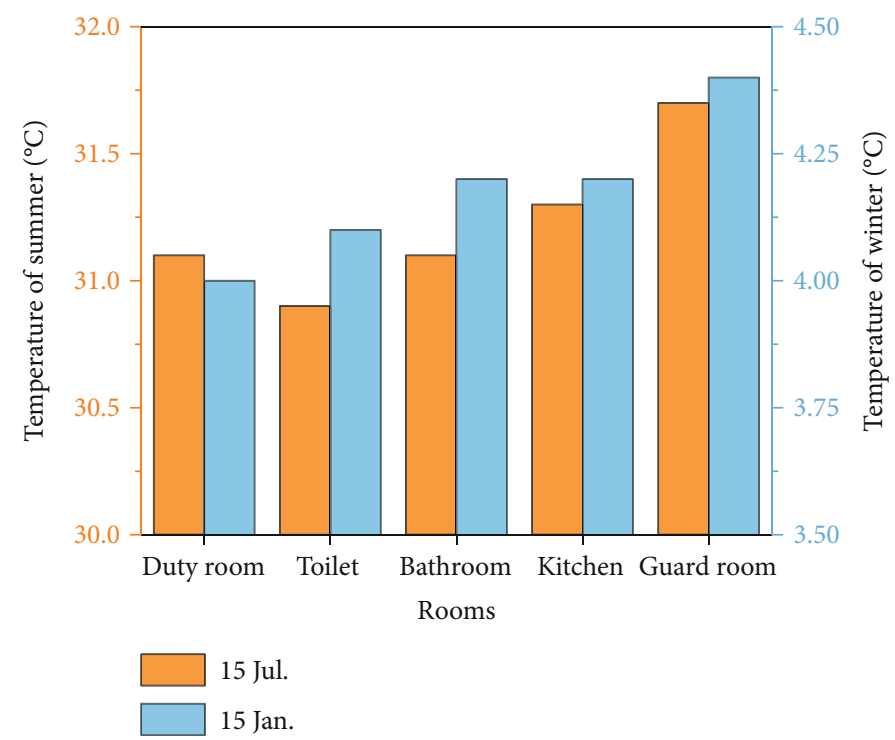

Figure 8: Annual average temperature of rooms in summer and winter.

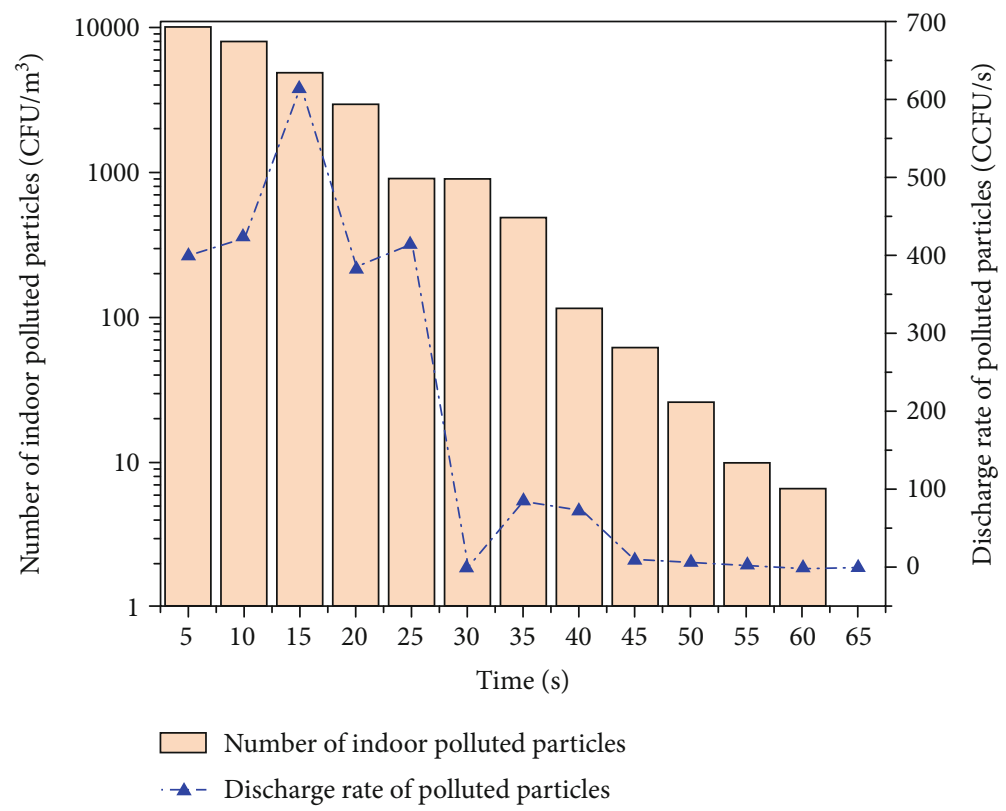

Figure 9: Variation of the number and discharge rate of polluted particles.

extreme cases, when all doors are open, the air entering the room can flow into any space in the room. In other words, the polluted particles can be emitted into any space in the room. The air velocity at the air inlet of the room is set as $1.5 \mathrm{~m} / \mathrm{s}$. The pressure difference between the front and rear of the exhaust fan is set as $20 \mathrm{~Pa}$. The air outlet is set as the pressure type of air outlet, and the pressure is equal to standard atmospheric pressure. Pedestal pans in the three toilets are, respectively, set as polluted particle emission sources. Each emission source is $0.5 \mathrm{~m}$ above the ground. The emission face area of polluted particles is set as $0.064 \mathrm{~m}^{2}$. Each emission face emits 400 polluted particles at a speed of $0.2 \mathrm{~m} / \mathrm{s}$ for five seconds.
The results show that the emitted polluted particles will not be ejected from the toilets and pollute other rooms obviously, even if the toilet door is not closed. Polluted particles from the toilets can be quickly discharged from the building under the action of exhaust fans. Figure 9 shows the variation of the number of indoor polluted particles and the change curve of the discharge rate of polluted particles from indoor to outdoor. At $25 \mathrm{~s}$, nearly half of polluted particles are discharged outdoors. At $40 \mathrm{~s}$, the concentration of polluted particles is lower than $2,500 \mathrm{CFU} / \mathrm{m}^{3}$, which meets the standard requirements [54]. At this time, there are only a few polluted particles in the toilets. At $64 \mathrm{~s}$, polluted particles in the toilets are entirely discharged. Moreover, the 


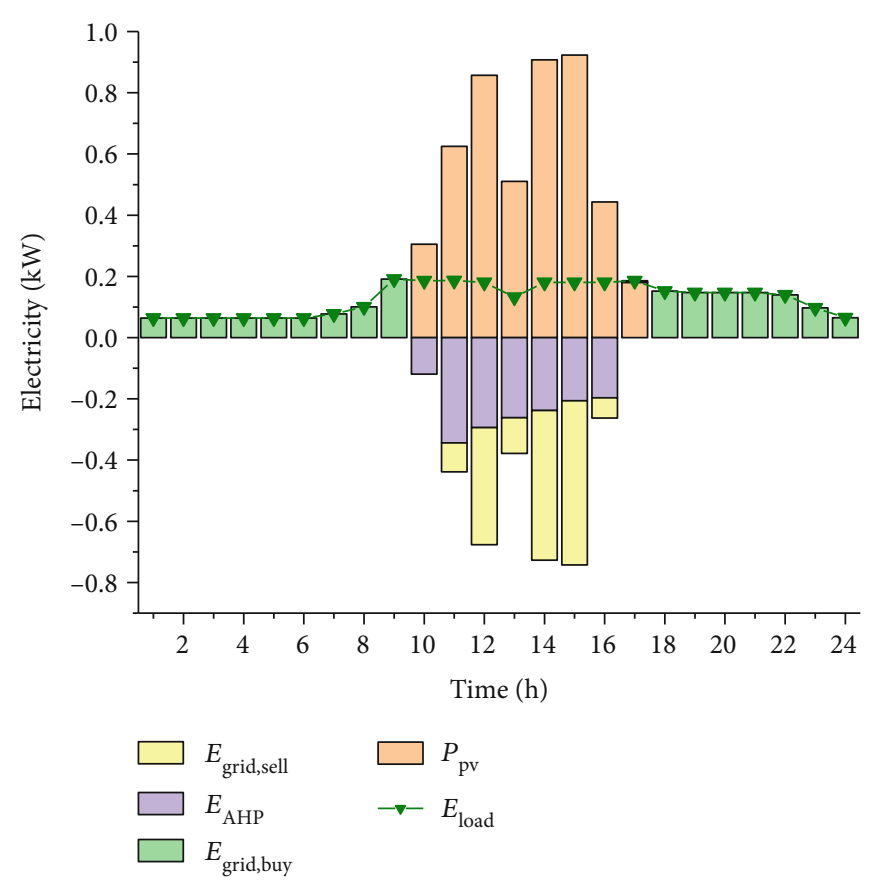

(a) Electrical balance (system 1)

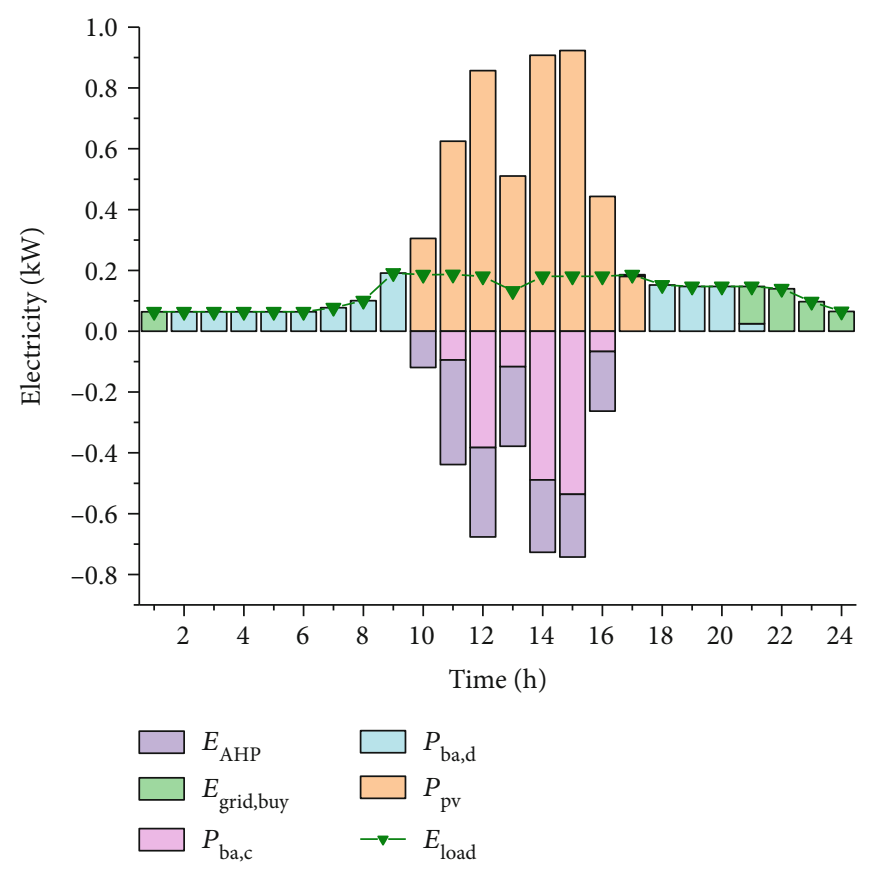

(c) Electrical balance (system 2)

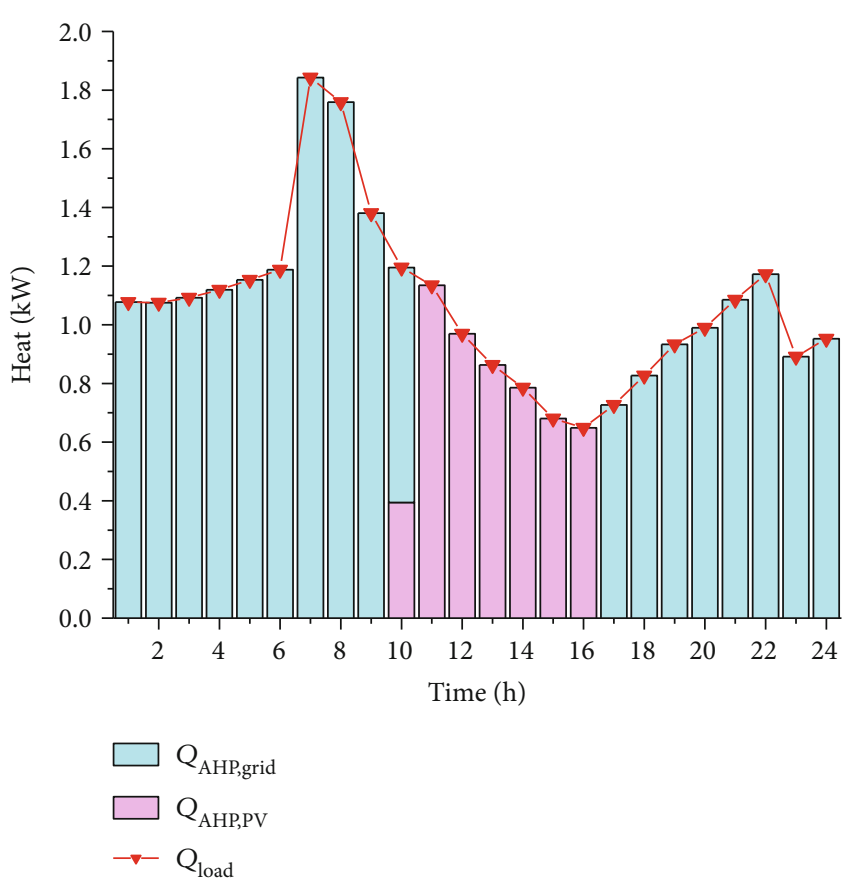

(b) Heat balance (system 1)

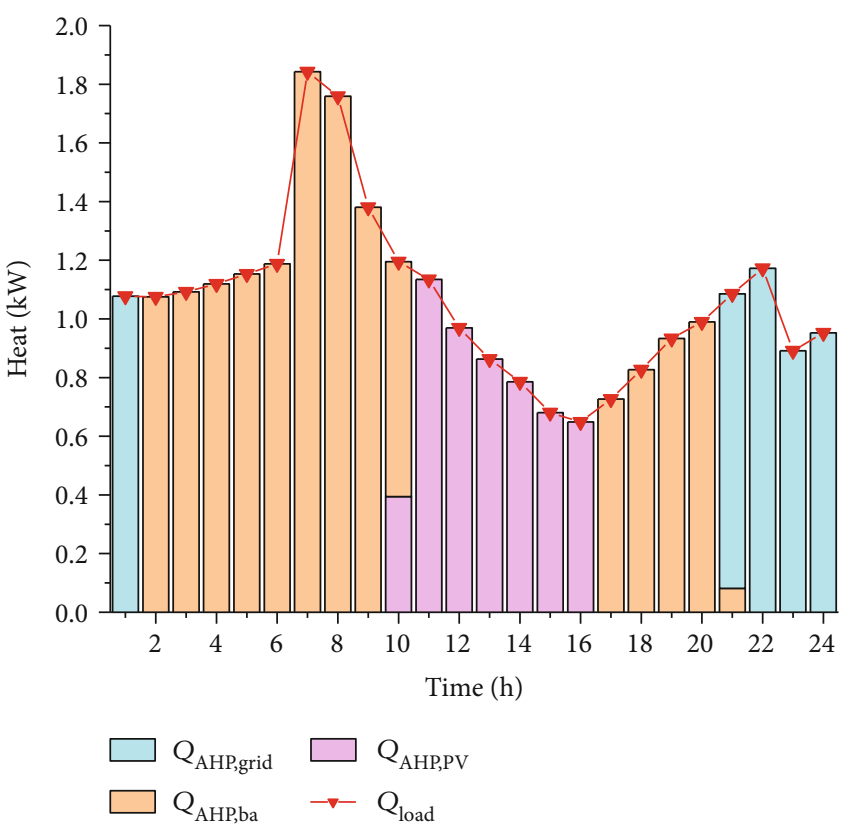

(d) Heat balance (system 2)

FIgURE 10: Energy balance between the system and users (15 Jan.).

discharge rate of polluted particles gradually increases between $5 \mathrm{~s}$ and $15 \mathrm{~s}$ and reaches the highest at $15 \mathrm{~s}$. After that, there is an overall decreasing trend of the discharge rate. After $45 \mathrm{~s}$, because of the small number of polluted particles, the discharge rate of polluted particles is relatively low. Therefore, the prefabricated auxiliary building can ensure a good indoor cleanliness environment.
4.4. Operation Performances and Cost Components of the Energy Supply System. Figure 10 is the electricity and heat balance diagram of system 1 and system 2 on a typical winter day (15 Jan). According to the solar radiation in Jinan and Equations (1)-(7), power generation of the PV system is calculated. The electricity generated by the PV system first is provided for users' electricity load. As seen in Figure 10(a) 


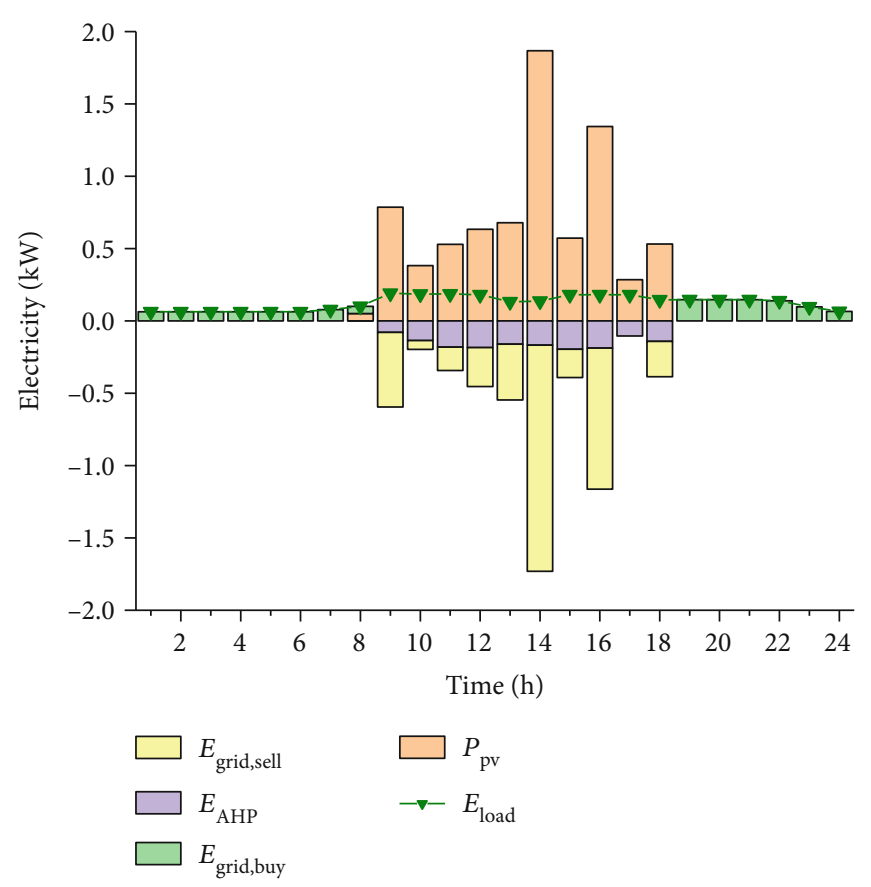

(a) Electrical balance (system 1)

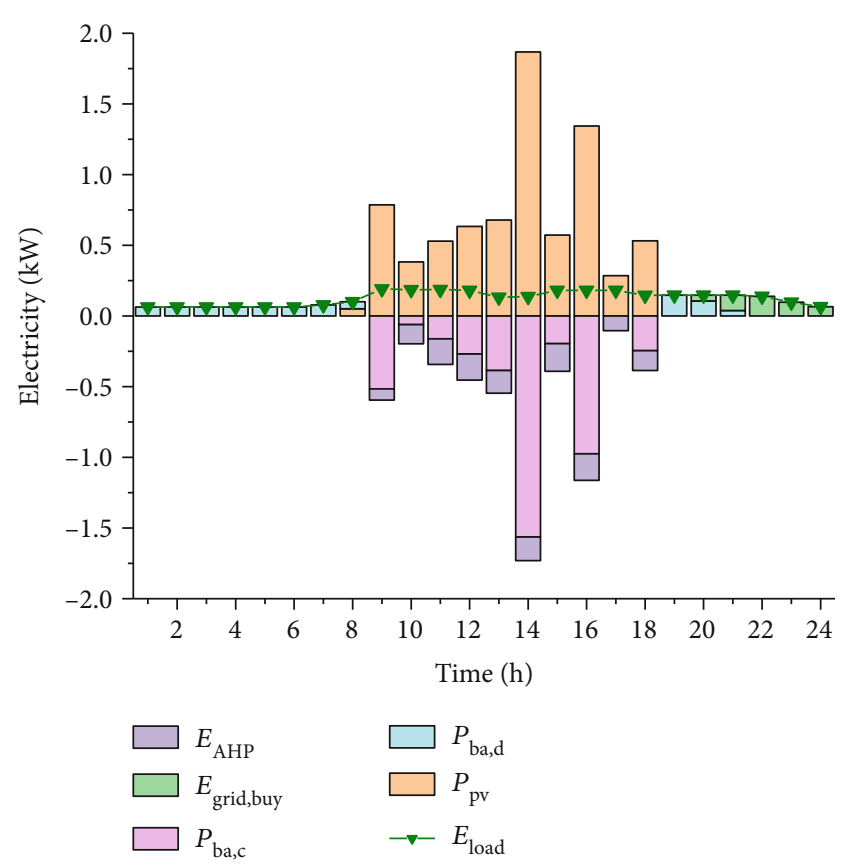

(c) Electrical balance (system 2)

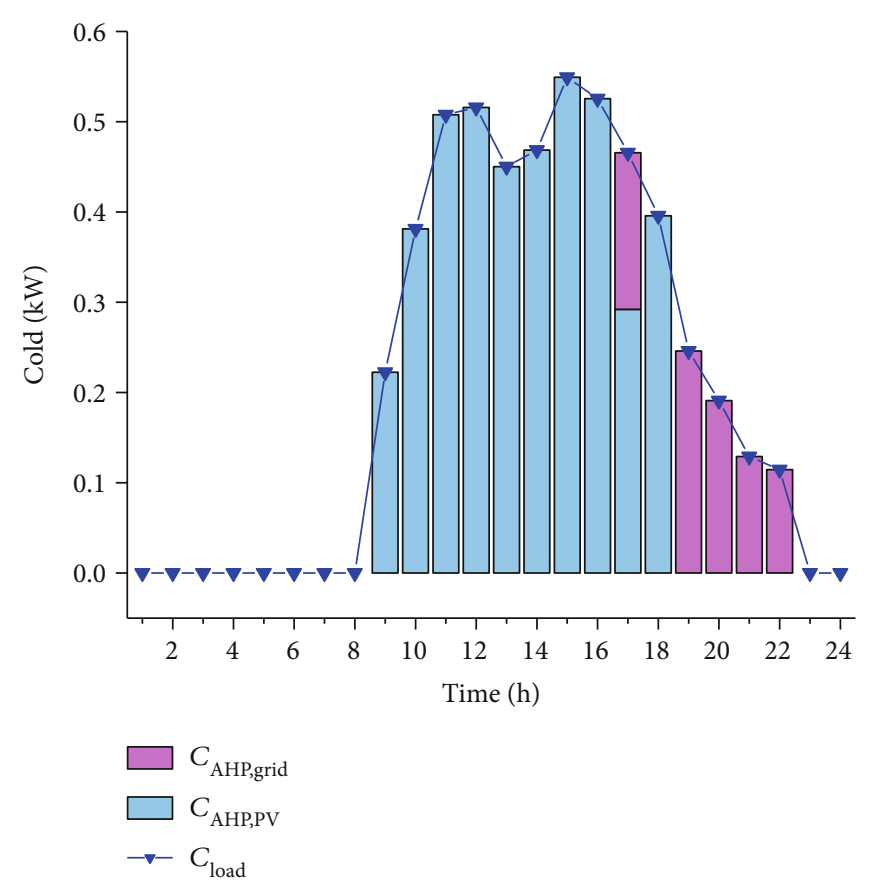

(b) Cold balance (system 1)

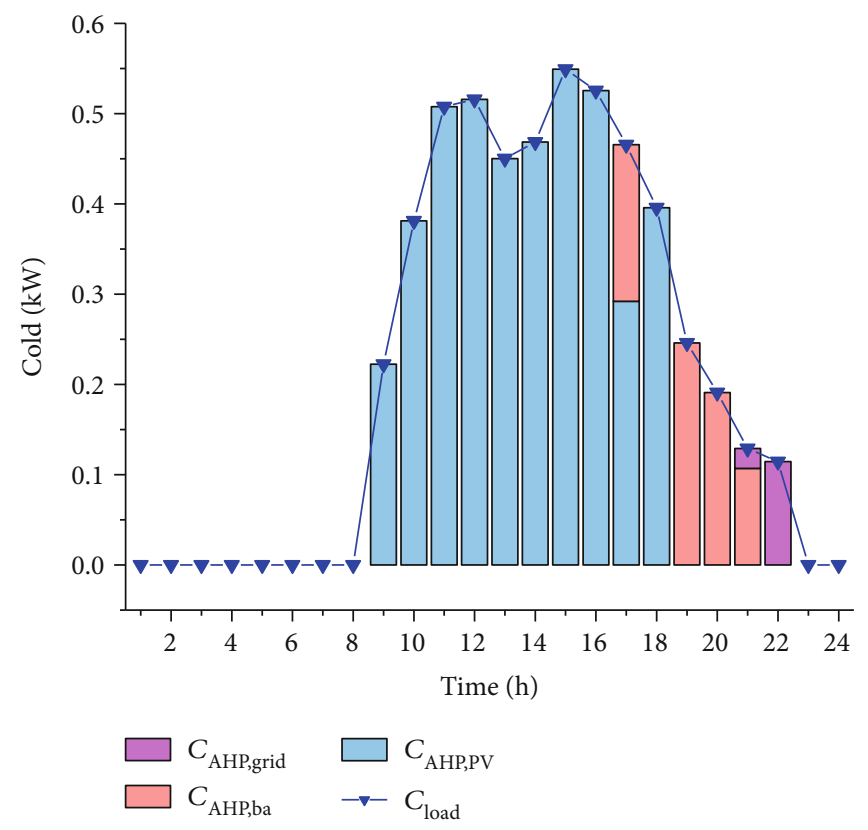

(d) Cold balance (system 2)

FIGURE 11: Energy balance between the system and users (15 Jul.).

of system 1, there exists sufficient solar irradiance from 10:00 to18:00. The PV system can produce enough electricity to meet users' electricity load within this time range, and there is still electricity remaining. This part will give priority to driving the AHP for refrigeration in summer and heating in winter. According to Equations (8)-(11), the electricity required by AHP for heating can be calculated. The surplus electricity is sold to the grid in the range of 11:00-17:00, and the insufficient load is supplemented by power purchase.
During the rest of the time, there is no PV power generation, so electricity needs to be purchased from the grid. As seen in Figure 10(c) of system 2, between 10:00 and 18:00, PV power generation meets the users' electricity load and drives AHP to operate. The redundant power is stored in ES as Equations (12)-(16). The discharge stored in ES as Equations (12)-(15) and (17) satisfies users' electricity load in this period, and the insufficient can be purchased from the state grid. 


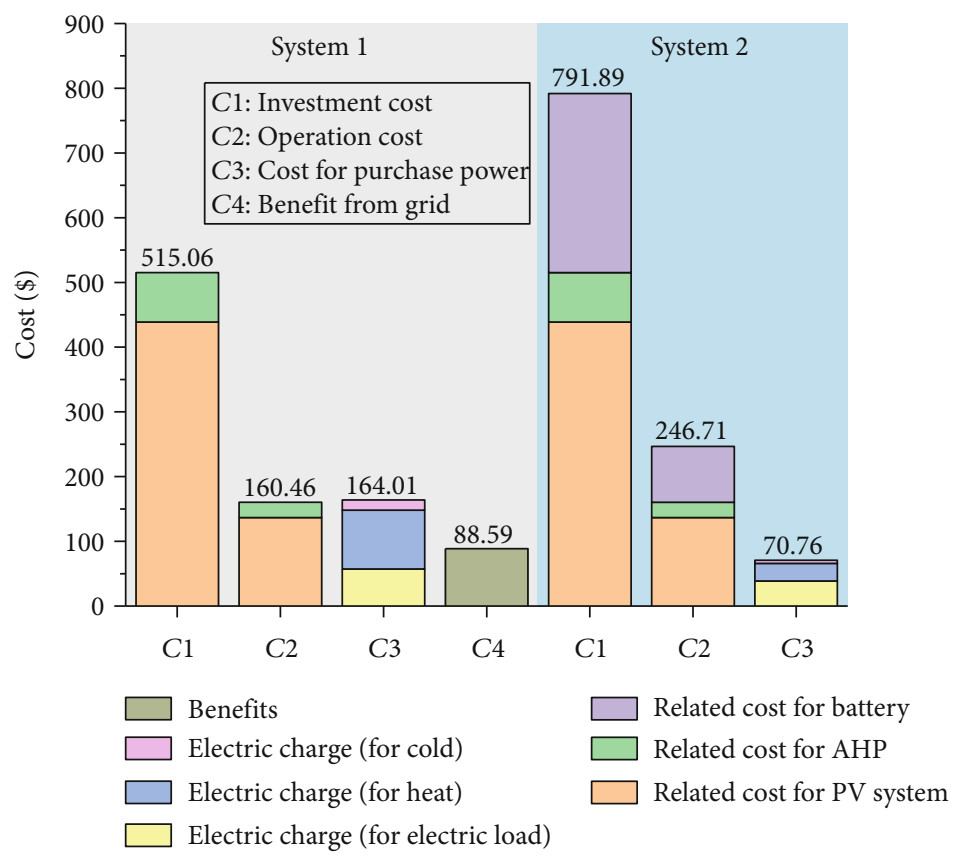

Figure 12: Cost components of the energy supply system.

Table 5: Price of purchasing and selling electricity [51].

\begin{tabular}{lcc}
\hline Items & Values \\
\hline & $10: 00-15: 00 ;$ & $7: 00-10: 00$ \\
Price of electricity purchased from grid $(\$ / \mathrm{kWh})$ & $18: 00-21: 00-18: 00$ & $21: 00-23: 00$ \\
& & 0.13 \\
Price of electricity sold to grid $(\$ / \mathrm{kWh})$ & & 0.04 \\
\hline
\end{tabular}

System 1 and system 2 all can meet the load demands. As seen in Figure 10(a), the system needs to purchase electricity from grid from 18:00 to 9:00 the next day. At noon, part of the excess electricity from PV system is used to drive AHP, and the other part is sold to grid for benefits. It is found in Figure $10(\mathrm{c})$ that the electricity purchased from grid in system 2 is less on the whole day, only $0.49 \mathrm{kWh}$ because the battery effectively plays the role of peak shaving and valley filling by absorbing the excess PV electricity. In addition, concerning the supply of heat load, system 1 needs to purchase electricity from grid to drive AHP to supplement the lack of heat load most of the time (Figure 10(b)). While system 2 can drive AHP through battery discharge to meet the heat load most of the time, meanwhile, less electricity is bought from grid (Figure 10(d)).

Figure 11 is the electricity and cold supply balance diagram of system 1 and system 2 on a typical summer day (15 Jul.). Compared with winter, the PV electricity generation has increased significantly, and the maximum power generation reaches $1.83 \mathrm{~kW}$. It can be seen in Figure 11(a) that the electricity sales of system 1 increases greatly, and most of the cold load can be provided by AHP driven by the electricity of PV at 9:00-18:00 (Figure 11(b)). However, it is still necessary to purchase electricity from the power grid at night to meet the shortage of electricity load and cold load. The battery of system 2 can store more electricity to meet part of the electrical load, and only a small amount of electricity from grid is required (Figure 11(c)). In addition, the AHP driven by battery discharge supplements part of the cold load from 19:00 to 21:00, meeting the maximum cold load of $0.25 \mathrm{kWh}$ at 19:00.

Figure 12 shows the annual cost composition of system 1 and system 2 . According to the capacity and per unit capacity investment cost of PV, ES, and AHP in Table 4, the investment cost $\left(C_{1}\right)$ of system 1 and system 2 can be obtained. The operation cost $\left(C_{2}\right)$ of system 1 and system 2 can also be acquired as shown in Table 4 . The cost for purchase power $\left(C_{3}\right)$ of system 1 and system 2 can be acquired based on the price of purchasing electricity in Table 5 and electricity quantity purchased $\left(E_{\text {gird,buy }}\right)$ as seen in Figures 10(a) and 10(c) and Figures 11(a) and 11(c). The benefit from grid $\left(C_{4}\right)$ of system 1 can be obtained in the same way.

As seen, the annual cost of system 1 is 839.53 \$, and the annual cost of system 2 is 1109.36 . Luerssen et al. [55] adopted $15 \mathrm{~kW}$ PV panels and $50 \mathrm{~kW}$ ground source heat 


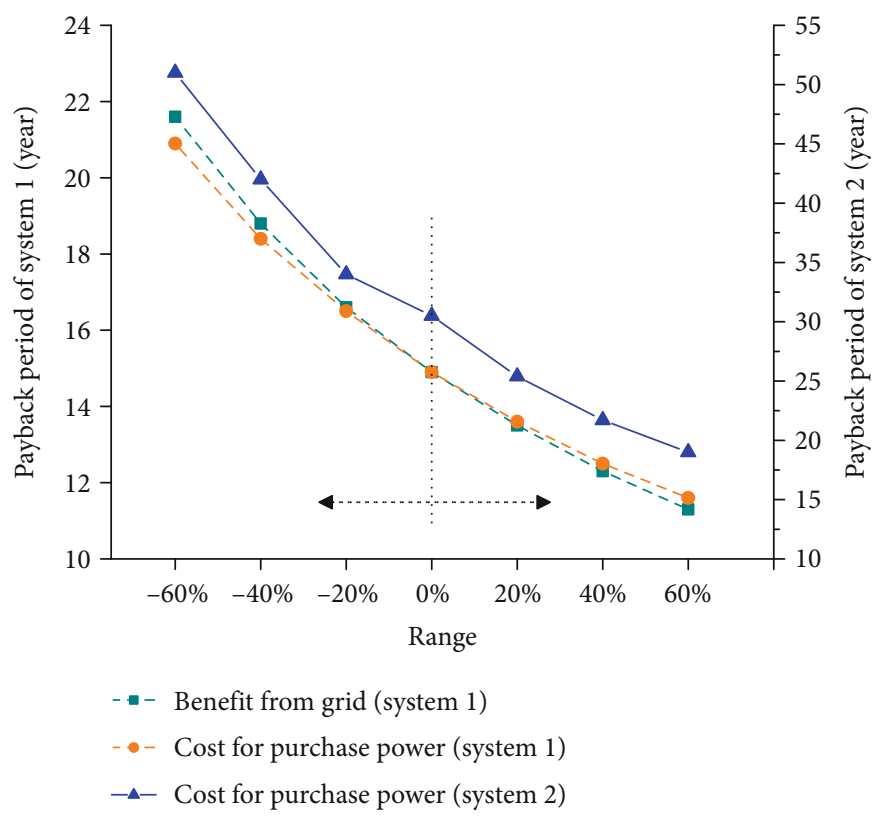

FIGURE 13: Sensitivity variation of the price of the electricity sold to grid and the price of the electricity purchased from the grid.

pump and calculated life cycle costs of 30 years (48842.36\$). Compared with the results obtained by Luerssen et al. [55], annual cost reduced by $788.54 \$, 518.71 \$$ in system 1 and system 2 , respectively. The high cost of system 2 (269.83\$) is due to the increase of battery, and its investment cost and operation cost have increased by $276.83 \$$ and $86.25 \$$, respectively. In addition, system 2 has significantly reduced the electricity charge from $164.01 \$$ to $70.76 \$$. This is because of the prominent role of battery making full use of solar energy. The surplus electricity of system 1 is sold to grid, and the benefit is $88.59 \$$. Since system 2 cannot sell electricity to grid, there is no economic benefit.

In order to explore the payback period of system 1 and 2, a separated system is selected as a reference. In this reference system, the electrical load is met by grid; the heat and cold loads are met by AHP driven by grid. There is no battery and PV system. Based on the reference system, the payback period of system 1 and 2 is obtained, according to different electricity price. Intuitively, Figure 13 shows the sensitivity variation of the price of the electricity sold to grid and the price of the electricity purchased from the grid, in which the price variation range is - $60 \%$ to $60 \%$ based on Table 4 . The payback period of system 1 is 15 years and that of system 2 is 30 years, when the electricity price is shown in Table 4 . The difference occurs because of the presence of battery and the economic benefit from grid. It can be seen that the payback period decreases with the increase of electricity prices. It indicates that the higher sold and purchased electricity prices induce the economic difference increased between the system $1 / 2$ and the reference system, which further reduces the payback period of system $1 / 2$ based on the reference system. In addition, with the increase of electricity price purchased from grid, the payback period of system 1 is reduced from 21.6 years to 11.3 years, and that of system 2 is reduced from 51 years to 19 years. Therefore, system 2 is greatly affected by the electricity price purchased from grid. Moreover, for every $20 \%$ increase in electricity selling price, the payback period of system 2 is reduced by an average of 1.7 years.

\section{Conclusion}

For a prefabricated auxiliary building, this paper performs a comprehensive evaluation and analysis, in terms of indoor environment and energy consumption. The following conclusions are obtained:

(1) The average indoor temperature in some rooms ranges between $16^{\circ} \mathrm{C}$ and $18^{\circ} \mathrm{C}$ in winter. Moreover, the temperature difference of different rooms mainly occurs in winter, and the bathroom has the lowest temperature (more than $16^{\circ} \mathrm{C}$ ). The average indoor temperatures of the prefabricated building can basically reach the heating standard $\left(18^{\circ} \mathrm{C}\right)$ in each climate region with the design of building envelope

(2) The average indoor temperature is $4.1^{\circ} \mathrm{C}$ and $31.1^{\circ} \mathrm{C}$ on typical days in winter and summer, respectively. The overall temperature level of the equipment duty room is the highest. The overall average indoor air velocity is $0.5 \mathrm{~m} / \mathrm{s}$ and $0.7 \mathrm{~m} / \mathrm{s}$ on typical days in winter and summer, respectively, and there is no obvious airflow dead corner in the rooms. The maximum indoor air velocity is $1.8 \mathrm{~m} / \mathrm{s}$ and $2 \mathrm{~m} / \mathrm{s}$. On the whole, there exist good thermal comfort and airflow distribution in prefabricated buildings

(3) Under the combined effects of natural and mechanical ventilation, indoor polluted particles from the toilets will not pollute other rooms. It takes $64 \mathrm{~s}$ for polluted particles to be discharged entirely outdoors 
from the beginning of emission, and the indoor air quality can meet the standard requirements after $40 \mathrm{~s}$. Pollution can be well controlled, and the prefabricated auxiliary building can provide a good indoor cleanliness environment

(4) In system 1 and system 2, the PV subsystem provides a large amount of electricity to meet user electrical load and drive the AHP. The battery of system 2 can absorb the excess PV electricity, which obviously reduces the amount electricity purchased from grid. Moreover, the annual cost of system 1 is $839.53 \$$, and the annual cost of system 2 is $1109.36 \$$ (269.83 \$ difference), and the benefit of system 1 is 88.59 \$. In addition, the payback period of system 1 and 2 decreases with the increase of electricity prices, especially system 2 . Annual cost reduced sharply in system 1 and system 2 comparing to the previous study, respectively. The payback period of system 2 is affected more significantly by the electricity price

Indoor thermal comfort, cleanliness, energy supply system, and energy consumption are investigated in a prefabricated auxiliary building. These findings can provide a comprehensive evaluation of the promotion feasibility of prefabricated auxiliary buildings.

\section{Abbreviations}

AHP: Air-source heat pump

CFD: Computational fluid dynamics

ES: $\quad$ Electrical storage

$k$ : $\quad$ Thermal conductivity

PBP: $\quad$ Payback period

PCM: Phase change materials

PLR: Partial load ratio

$\mathrm{PM}_{2.5}$ : Particulate matter with an aerodynamic diameter of less than $2.5 \mu \mathrm{m}$

PV: $\quad$ Photovoltaic

PV/T: Photovoltaic-thermal

RMSE: Root-mean square error.

\section{Variables}

A: Polynomial fitting coefficient

C: $\quad$ Cost

COP: Coefficient of performance

E: $\quad$ Power consumption

F: $\quad$ Factor

F: $\quad$ Efficiency

I: $\quad$ Current

$K: \quad$ Thermal conductivity

$P$ : $\quad$ Power generation

PBP: Payback period

$Q$ : $\quad$ Cold energy or heating energy

$S: \quad$ Area

SOC: State of charge

T: $\quad$ Temperature

$V$ : Voltage

$\Phi: \quad$ Solar radiation.

\section{Data Availability}

The code data used to support the findings of this study can not be shared at this time as the data also forms part of an ongoing study.

\section{Conflicts of Interest}

The authors declare that there is no conflict of interest.

\section{Acknowledgments}

This work was supported by the Science and Technology Project of State Grid Corporation of China (Research on Deepening Design Technology and Construction Effectiveness System in the Modular Construction of 35-220 kV Substations, 5200-202055134A-0-0-00, SGTYHT/19-JS-215).

\section{References}

[1] S. M. Wang, C. J. Wang, W. L. Li, and D. Zhao, "Study on the operational efficiency of prefabricated building industry bases in Western China based on the DEA model," Arabian Journal of Geosciences, vol. 14, no. 6, 2021.

[2] R. Minunno, T. O'Grady, G. M. Morrison, and R. L. Gruner, "Investigating the embodied energy and carbon of buildings: a systematic literature review and meta-analysis of life cycle assessments," Renewable and Sustainable Energy Reviews, vol. 143, article 110935, 2021.

[3] N. A. Megahed and E. M. Ghoneim, "Indoor air quality: rethinking rules of building design strategies in post- pandemic architecture," Environmental Research, vol. 193, article 110471, 2021.

[4] A. Mellalou, W. Riad, S. K. Hnawi, A. Tchenka, A. Bacaoui, and A. Outzourhit, "Experimental and CFD investigation of a modified uneven-span greenhouse solar dryer in no-load conditions under natural convection mode," International Journal of Photoenergy, vol. 2021, Article ID 9918166, 12 pages, 2021.

[5] B. Y. Yun, J. H. Park, S. Yang, S. Wi, and S. Kim, "Integrated analysis of the energy and economic efficiency of PCM as an indoor decoration element: application to an apartment building," Solar Energy, vol. 196, pp. 437-447, 2020.

[6] W. van Helden, M. Yamaha, C. Rathgeber et al., "IEA SHC Task 42 / ECES Annex 29 - Working Group B: Applications of Compact Thermal Energy Storage," Energy Procedia, vol. 91, pp. 231-245, 2016.

[7] Q. Al-Yasiri and M. Szabo, "Incorporation of phase change materials into building envelope for thermal comfort and energy saving: a comprehensive analysis," Journal of Building Engineering, vol. 36, article 102122, 2021.

[8] M. Rabani, H. B. Madessa, and N. Nord, "Achieving zeroenergy building performance with thermal and visual comfort enhancement through optimization of fenestration, envelope, shading device, and energy supply system," Sustainable Energy Technologies and Assessments, vol. 44, article 101020, 2021.

[9] K. Zhao, J. T. Weng, and J. Ge, "On-site measured indoor thermal environment in large spaces of airports during winter," Building and Environment, vol. 167, article 106463, 2020.

[10] G. Kim, L. Schaefer, T. S. Lim, and J. T. Kim, “Thermal comfort prediction of an underfloor air distribution system in a 
large indoor environment," Energy and Buildings, vol. 64, pp. 323-331, 2013.

[11] H. H. Ali and R. Al-Hashlamun, "Assessment of indoor thermal environment in different prototypical school buildings in Jordan," Alexandria Engineering Journal, vol. 58, no. 2, pp. 699-711, 2019.

[12] M. F. Gabriel, F. Felgueiras, R. Batista et al., "Indoor environmental quality in households of families with infant twins under 1 year of age living in Porto," Environmental Research, vol. 198, article 110477, 2021.

[13] C. R. He, L. D. Morawska, J. Hitchins, and D. Gilbert, "Contribution from indoor sources to particle number and mass concentrations in residential houses," Atmospheric Environment, vol. 38, no. 21, pp. 3405-3415, 2004.

[14] M. F. Yassin, B. E. Y. AlThaqeb, and E. A. E. Al-Mutiri, "Assessment of indoor $\mathrm{PM}_{2.5}$ in different residential environments," Atmospheric Environment, vol. 56, pp. 65-68, 2012.

[15] K. E. Agbo, C. Walgraeve, J. I. Eze, P. E. Ugwoke, P. O. Ukoha, and H. Van Langenhove, "A review on ambient and indoor air pollution status in Africa," Atmospheric Pollution Research, vol. 12, no. 2, pp. 243-260, 2021.

[16] Z. Li, Q. Wen, and R. Zhang, "Sources, health effects and control strategies of indoor fine particulate matter (PM2.5): a review," Science of the Total Environment, vol. 586, pp. 610-622, 2017.

[17] H. H. Zhang, D. Yang, V. W. Y. Tam et al., "A critical review of combined natural ventilation techniques in sustainable buildings," Renewable and Sustainable Energy Reviews, vol. 141, article 110795, 2021.

[18] H. Hong, Z. Yidan, Z. Hailong, and S. Xinyi, "Study on the distribution characteristics and purification effect of formaldehyde in decorated indoors under different ventilation methods," IOP Conference Series: Earth and Environmental Science, vol. 680, no. 1, article 012101, 2021.

[19] M. Ncube and S. Riffat, "Developing an indoor environment quality tool for assessment of mechanically ventilated office buildings in the UK - a preliminary study," Building and Environment, vol. 53, pp. 26-33, 2012.

[20] J. Madureira, I. Paciência, J. C. Rufo, C. Pereira, J. P. Teixeira, and F. E. de Oliveira, "Assessment and determinants of airborne bacterial and fungal concentrations in different indoor environments: homes, child day-care centres, primary schools and elderly care centres," Atmospheric Environment, vol. 109, pp. 139-146, 2015.

[21] A. Zabnienska-Gora, N. Khordehgah, and H. Jouhara, "Annual performance analysis of the PV/T system for the heat demand of a low- energy single-family building," Renewable Energy, vol. 163, pp. 1923-1931, 2021.

[22] N. M. Isa, H. S. Das, C. W. Tan, A. H. M. Yatim, and K. Y. Lau, "A techno-economic assessment of a combined heat and power photovoltaic/fuel cell/battery energy system in Malaysia hospital," Energy, vol. 112, pp. 75-90, 2016.

[23] D. Marini, R. A. Buswell, and C. J. Hopfe, "Sizing domestic airsource heat pump systems with thermal storage under varying electrical load shifting strategies," Applied Energy, vol. 255, article 113811, 2019.

[24] Y. J. Zhang, J. H. Hao, Z. H. Ge, F. X. Zhang, and X. Z. Du, "Optimal clean heating mode of the integrated electricity and heat energy system considering the comprehensive energycarbon price," Energy, vol. 231, article 120919, 2021.

[25] Z. Liu, G. Fan, D. Sun et al., "A novel distributed energy system combining hybrid energy storage and a multi- objective opti- mization method for nearly zero-energy communities and buildings," Energy, vol. 239, article 122577, 2022.

[26] R. Alayi, M. H. Ahmadi, A. R. Visei, S. Sharma, and A. Najafi, "Technical and environmental analysis of photovoltaic and solar water heater cogeneration system: a case study of Saveh City," International Journal of Low-Carbon Technologies, vol. 16, no. 2, pp. 447-453, 2021.

[27] M. Alessandro, N. Aste, D. P. Claudio, and L. Fabrizio, "Photovoltaic-thermal solar-assisted heat pump systems for building applications: integration and design methods," Energy and Built Environment, 2021.

[28] Y. Wang, Y. Zhang, J. Hao et al., "Modeling and operation optimization of an integrated ground source heat pump and solar PVT system based on heat current method," Solar Energy, vol. 218, pp. 492-502, 2021.

[29] A. Cheema, M. F. Shaaban, and M. H. Ismail, “A novel stochastic dynamic modeling for photovoltaic systems considering dust and cleaning," Applied Energy, vol. 300, article 117399, 2021.

[30] J. Yi, E. R. Weber, C. W. Lan, S. Bremner, and D. H. Kim, "Photoenergy: progress in Si-related solar cells for a low cost and high efficiency," International Journal of Photoenergy, vol. 2012, Article ID 486706, 2012.

[31] Y. Wang, Z. Rao, J. Liu, and S. Liao, “An optimized control strategy for integrated solar and air-source heat pump water heating system with cascade storage tanks," Energy \& Buildings, vol. 210, article 109766, 2020.

[32] J. Varaprasad and D. S. Reddy, "Coyote optimization algorithm for optimal allocation of interline -Photovoltaic battery storage system in islanded electrical distribution network considering EV load penetration," Journal of Energy Storage, vol. 41, article 102981, 2021.

[33] Z. Wang, Y. Gu, H. Liu, and C. Li, "Optimizing thermalelectric load distribution of large-scale combined heat and power plants based on characteristic day," Energy Conversion and Management, vol. 248, article 114792, 2021.

[34] J. Jia, B. Liu, L. Ma, H. Wang, D. Li, and Y. Wang, "Energy saving performance optimization and regional adaptability of prefabricated buildings with PCM in different climates," Case Studies in Thermal Engineering, vol. 26, article 101164, 2021.

[35] G. Comodi, A. Bartolini, F. Carducci, B. Nagaranjan, and A. Romagnoli, "Achieving low carbon local energy communities in hot climates by exploiting networks synergies in multi energy systems," Applied Energy, vol. 256, article 103901, 2019.

[36] S. Liang, L. Ye, J. Qi, H. Ning, and J. Hang, "Study on energy consumption of Sino - German building in uncertain environment," IFAC PapersOnline, vol. 50, no. 2, pp. 104-109, 2017.

[37] J. Dong, Y. Li, W. Zhang, L. Zhang, and Y. Lin, "Impact of residential building heating on natural gas consumption in the south of China: taking Wuhan city as example," Energy and Built Environment, vol. 1, no. 4, pp. 376-384, 2020.

[38] L. Zhang, L. Za, C. Hou, J. Hou, D. Wei, and Y. Hou, “Optimization analysis of thermal insulation layer attributes of building envelope exterior wall based on DeST and life cycle economic evaluation," Thermal Engineering, vol. 14, article 100410, 2019.

[39] L. Shi, H. Zhang, Z. Li, Z. Luo, and J. Liu, "Optimizing the thermal performance of building envelopes for energy saving in underground office buildings in various climates of China," Tunnelling and Underground Space Technology, vol. 77, pp. 26-35, 2018. 
[40] Y. Sheng, Z. Miao, J. Zhang, X. Lin, and H. Ma, "Energy consumption model and energy benchmarks of five-star hotels in China," Energy and Buildings, vol. 165, pp. 286-292, 2018.

[41] M. Azaroual, M. Ouassaid, and M. Maarouf, "Optimal energy management strategy in a grid-tied system with PV, wind, and ESS considering environmental aspect.," in 2021 12th International Renewable Engineering Conference (IREC), pp. 322-327, Amman, Jordan, 2021.

[42] N. Mohammadkhani, M. Sedighizadeh, and M. Esmaili, "Energy and emission management of CCHPs with electric and thermal energy storage and electric vehicle," Thermal Science and Engineering Progress, vol. 8, pp. 494-508, 2018.

[43] X. Yang, Z. Leng, S. Xu et al., "Multi-objective optimal scheduling for CCHP microgrids considering peak-load reduction by augmented $\varepsilon$-constraint method," Renewable Energy, vol. 172, pp. 408-423, 2021.

[44] Y. Wang, L. Tang, Y. Yang, W. Sun, and H. Zhao, "A stochastic-robust coordinated optimization model for CCHP micro-grid considering multi-energy operation and power trading with electricity markets under uncertainties," Energy, vol. 198, article 117273, 2020.

[45] S. Lu, Y. Li, and H. Xia, "Study on the configuration and operation optimization of CCHP coupling multiple energy system," Energy Conversion and Management, vol. 177, pp. 773-791, 2018.

[46] Y. Deng, Y. Liu, R. Zeng et al., "A novel operation strategy based on black hole algorithm to optimize combined cooling, heating, and power-ground source heat pump system," Energy, vol. 229, article 120637, 2021.

[47] X. B. Zhang, D. Gamage, and A. Ukil, "Rising and falling edge compensation based faster control strategy for hybrid energy storage system in PV microgrid," Electric Power Systems Research, vol. 190, article 106856, 2021.

[48] X. Zhang, Y. H. Hu, W. Mao et al., "A grid-supporting strategy for cascaded H-bridge PV converter using VSG algorithm with modular active power reserve," IEEE Transactions on Industrial Electronics, vol. 68, no. 1, pp. 186-197, 2021.

[49] T. Tewari, A. Mohapatra, and S. Anand, "Coordinated control of OLTC and energy storage for voltage regulation in distribution network with high PV penetration," IEEE Transactions on Sustainable Energy, vol. 12, no. 1, pp. 262-272, 2021.

[50] J. Guo, P. Zhang, D. Wu et al., "A new collaborative optimization method for a distributed energy system combining hybrid energy storage," Sustainable Cities and Society, vol. 75, article 103330, 2021.

[51] J. J. Wang, Y. Z. Chen, C. Dou, Y. F. Gao, and Z. Zhao, "Adjustable performance analysis of combined cooling heating and power system integrated with ground source heat pump," Energy, vol. 163, pp. 475-489, 2018.

[52] Y. D. Torres, H. H. Herrera, M. A. A. G. Plasencia et al., "Heating ventilation and air-conditioned configurations for hotelsan approach review for the design and exploitation," Energy Reports, vol. 6, pp. 487-497, 2020.

[53] Z. Liu, M. Zhang, G. Cao, S. Tang, H. Liu, and L. Wang, "Influence of air supply velocity and room temperature conditions on bioaerosols distribution in a class I operating room," Building and Environment, vol. 204, article 108116, 2021.
[54] Z. J. Liu, S. Y. Ma, G. Q. Cao, C. Meng, and B. J. He, "Distribution characteristics, growth, reproduction and transmission modes and control strategies for microbial contamination in HVAC systems: a literature review," Energy and Buildings, vol. 177, pp. 77-95, 2018.

[55] C. Luerssen, O. Gandhi, T. Reindl, C. Sekhar, and D. Cheong, "Life cycle cost analysis (LCCA) of PV-powered cooling systems with thermal energy and battery storage for off-grid applications," Applied Energy, vol. 273, article 115145, 2020. 